\title{
Histories of Deposition: creating chronologies for the Late Bronze Age-Early Iron Age transition in Southern Britain
}

\author{
Kate Waddington ${ }^{1}$, Alex Bayliss ${ }^{2}$, Thomas Higham ${ }^{3}$, Richard Madgwick ${ }^{4}$, and Niall Sharples ${ }^{4}$ \\ ${ }^{1}$ School of History, Welsh History, and Archaeology, Bangor University, Bangor, Gwynedd, \\ L57 2DG, UK (k.waddington@ bangor.ac.uk) \\ ${ }^{2}$ Biological \& Environmental Sciences, University of Stirling, Stirling, FK9 4LA, UK \\ ${ }^{3}$ Oxford Radiocarbon Accelerator Unit, University of Oxford, Dyson Perrins Building, South \\ Parks Road, Oxford, OX1 3QY, UK \\ ${ }^{4}$ Department of Archaeology, Cardiff University, John Percival Building, Colum Drive, \\ Cardiff, CF10 3EU, UK
}

\section{Summary}

The Late Bronze Age-Early Iron Age midden sites of Southern Britain are amongst the richest archaeological sites in the country. The organic accumulations contain substantial quantities of animal bone, decorated ceramics, metalwork and other objects; the often deep stratigraphy allows for a number of changes in material culture and depositional practices, food production and consumption, and shifts in social identities, to be traced through time. The well-stratified assemblages also provide useful materials for dating the deposits. This has been problematic, however, as the majority of samples produce unhelpfully broad calibrated radiocarbon dates, due to the effects of the earlier Iron Age plateau in the calibration curve, which spans c. 800-400 BC. Interpretation has relied on current understandings of the associated pottery and metalwork, which placed most midden sites somewhere between the tenth and the seventh/mid-sixth centuries cal BC (c. 1000-600/550 cal BC), but the end-date of these traditions is particularly uncertain. This article addresses this issue by presenting the results of a new dating programme for East Chisenbury in Wiltshire, southern England. Twenty-eight radiocarbon determinations were obtained and combined with the site stratigraphy in a Bayesian chronological model. The results have transformed the chronology of the site, with the end of the occupation sequence being pulled forward some one-hundred years, to the mid-to-late fifth century cal BC. These new chronologies have significant implications for our understanding of the Late Bronze Age-Early Iron Age transition and require a revision of the currently accepted chronology of post-Deverel Rimbury decorated wares in south-central England.

\section{Introduction}

The plateau in the radiocarbon calibration curve in the middle of the first millennium $\mathrm{BC}$ is one of the most extreme encountered in the Holocene, and has hindered the chronological analysis of sites and objects dating to the earlier Iron Age in Britain. The plateau is a flattening of the calibration curve, which makes chronological resolution of individual dates very poor between $c$. 800-400 BC. The midden sites of southern Britain, which importantly produce large assemblages of pottery, metalwork, and animal bones, are a feature of this period. Limited numbers of radiocarbon determinations have been produced, and their calibrated dates which extend into the plateau are unhelpfully broad. The chronology of these sites has therefore traditionally relied on the typological analysis of the associated ceramic 
and metalwork assemblages. Current understanding of post-Deverel Rimbury plain and decorated wares, alongside Ewart Park and Llyn Fawr metalwork, has placed most midden sites at $c$. 1000-600 BC and, based on the large assemblages of decorated post-DeverelRimbury wares, it is widely argued that the main bulk of the deposits formed between $c$. 800600/550 BC. This period is referred to as the Late Bronze Age-Early Iron Age transition, or the Llyn Fawr metalwork period. Whilst the beginning of this final Bronze Age metalworking period clearly lies at $c .800 \mathrm{cal} \mathrm{BC}$, the end of this period - and its associated material assemblages and sites - has proven difficult to date due to the earlier Iron Age plateau.

Over the past two decades, two major radiocarbon projects have successfully tackled the chronology of later prehistoric metalwork sequences dating to the later Bronze Age (Needham et al. 1997) and the later Iron Age (Garrow et al. 2009), but there is a notable gap in the sequence, which at the time was regarded as 'impossible to bridge using radiocarbon dating, given the plateau in the calibration curve' (Garrow et al. 2009, 80; see also Needham et al. 1997, 98). The deeply stratified accumulations at some of the midden sites provide relative sequences that can offer strong archaeological prior beliefs in the Bayesian modelling of radiocarbon dates (see Whittle and Bayliss 2007). This has the potential to constrain dates which fall on the radiocarbon plateau, as well as to test and refine existing understanding of the dating of artefact typologies and settlement sequences in this period.

This article presents the results of a dating programme for the substantial midden site of East Chisenbury in Wiltshire. East Chisenbury was chosen for the analysis due to its preservation. The mound survives to a thickness of $3 \mathrm{~m}$ and covers an area of at least $2 \mathrm{ha}$, and it was the focus of trial excavations by David McOmish, David Field, and Graham Brown in the early 1990s (McOmish 1996; McOmish et al. 2002, 2010). The excavations produced a large assemblage of well-preserved pottery and animal bones, and the site is unusual in that the midden soils are visibly stratified due to the presence of chalk surfaces and different coloured layers. Twenty-eight radiocarbon dates from primary animal bone samples and charred food residues on pottery were obtained and combined with the excavated stratigraphic sequences in a Bayesian chronological model. The principal aims were to determine whether Bayesian modelling, in circumstances where there is strong prior information, can produce robust chronologies that are of sufficient precision to be archaeologically useful in this period, and to test whether current understandings of the chronology of these sites is accurate. It therefore aimed to fill the current lacuna in calendrical dating in the middle centuries of the first millennium BC. The resultant timescale, outlined below, has significant implications for understanding the chronology of midden sites and some of their associated material assemblages.

\section{The archaeology of Late Bronze Age - Early Iron Age midden sites}

Around thirty Late Bronze Age/Early Iron Age midden sites have been identified in southern Britain (see McOmish 1996; Tubb 2011; Waddington 2009, ch. 4), and they vary in size, with deposits ranging in thickness from $c .0 .15-0.30 \mathrm{~m}$ at Llanmaes in the Vale of Glamorgan (Gwilt et al. 2006), c. $0.50 \mathrm{~m}$ at Runnymede Bridge in the Thames Valley (Area 16 East; Needham and Spence 1996), to $3 \mathrm{~m}$ at East Chisenbury in the Vale of Pewsey. The largest sites are concentrated in Wiltshire and, as well as East Chisenbury, excavated sites include Potterne (Lawson 2000), All Cannings Cross (Cunnington 1923; Barrett and McOmish 2008; Tullett 2011) and Westbury (Wessex Archaeology 2004a; 2004b). Midden deposits have also 
been investigated on the Isle of Purbeck, such as Eldon's Seat (Cunliffe and Phillipson 1968), Rope Lake Hole (Woodward 1986), Compact Farm, and Worth Matravers (Graham et al. 2002; Ladle forthcoming). The Thames Valley is also productive and, as well as Runnymede Bridge on the Berkshire-Surrey border (Needham and Spence 1996; Needham 2000), excavated sites include Wallingford (Thomas et al. 1986; Cromarty et al. 2006), Whittenham Clumps/Castle Hill (Allen et al. 2010) and Woodeaton (Harding 1987) in Oxfordshire. There is also an isolated northern outlier at Whitchurch in Warwickshire (Waddington and Sharples 2011).

As a group, these sites have many shared characteristics. The dark earths that typically make up the mounds are rich in dung, ash, plant matter, and stabling waste (Macphail 2000; 2010). The decaying residues were not spread as fertiliser on fields, but instead became the location for communal events which resulted in the deposition of a range of objects and substances. The mixed character of some of the layers suggests that the enriched soils were sometimes exploited in situ as garden plots (Guttmann 2005). The sites typically produce enormous quantities of fragmented pottery and butchered animal bones, as well as disarticulated and modified human bones and a wide variety of objects, which are the result of conspicuous community feasts, exchange ceremonies, and funerary and life-cycle rites (e.g. see Lawson et al. 2000; McOmish 1996; Needham and Spence 1996; Waddington 2009; forthcoming). Communities were gathering with their animals at these places at specific times in the year, probably in autumn and spring - when animals were moved to either higher or lower ground - and these were occasions for large-scale gatherings which drew people and their animals from the surrounding landscapes and beyond (Madgwick and Mulville 2015a; Madgwick et al. 2012a). The seasonal nature to occupation practices is supported by the animal bone assemblages, which demonstrate autumn cull patterns at Potterne (Locker 2000, 114-18) and spring cull patterns at East Chisenbury (Serjeantson et al. 2010, 63-64).

Late Bronze Age settlements, indicated by the presence of hearths and post-holes, have been identified at the base of the midden soils at many sites, including Potterne, East Chisenbury, Eldon's Seat, Runnymede Bridge, Whittenham Clumps, Llanmaes (Gwilt et al. 2016), and Whitchurch (Waddington and Sharples 2011). Activity areas within the midden soils are also indicated by laid stone or chalk surfaces, which appear suspended in the homogenous dark earth sequences, such as at All Cannings Cross and East Chisenbury (McOmish and Barrett 2008; McOmish et al. 2010, 87-88).

East Chisenbury is located on the south side of the Vale of Pewsey an area of southern England that provides the source for both the Bristol and the Salisbury Avon and lies just to the south of the Kennet Valley. It therefore has easy access to the west, south and east coast. The Vale itself appears to have been a fairly wet area that was not intensively occupied but the chalk downlands that surround the Vale were densely settled. An unusually large number of Late Bronze Age/Early Iron Age settlements have been recognised by field walking and aerial photography (McOmish 1996; Tubb 2011) and this includes the middens at Potterne, at the west end of the Vale, and All Cannings Cross, on the east side of the Vale. However, there are other dark earth deposits that produce large ceramic assemblages that could also be middens, though not necessarily as complex or extensive as East Chisenbury. Several of the pottery scatters are associated with enclosures and recent work at East Chisenbury has confirmed that this midden was also defined by a ditch (Wessex Archaeology 2017). Iron Age hillforts are not that common in the Vale but All Cannings Cross was overlooked by the 
hillfort at Rybury and East Chisenbury is faced across the Avon Valley by the hillfort of Casterley Camp, though both these enclosures may be later constructions (Tubb 2011, 195).

\section{Previous interpretations of calendar dating}

The southern British midden sites have produced material spanning the later Bronze Age and the earlier Iron Age. The later Bronze Age is typically divided into three phases; the Middle Bronze Age (c. 1500-1150 cal BC), the Late Bronze Age (c. 1150-800 cal BC) and the Late Bronze Age-Early Iron Age transition (c. 800-600 cal BC; also classified as the 'Earliest Iron Age' or Llyn Fawr metalwork period; Needham 2007; Needham 1996). The succeeding Iron Age period in Wessex is divided - mainly on the basis of the interpretation of the pottery assemblages - into an Early (c. 600-400/300 BC), Middle (c. 400/300-100/50 BC) and Late period (c. 100/50 BC-AD 43; Cunliffe 1984; Sharples 2010, 322-24). Such a detailed chronological system for the Iron Age is impossible in areas where dateable ceramic and metalwork assemblages are limited, and Haselgrove and Pope (2007) proposed an alternate model which separates the period into two phases - the Earlier (c. 800-400 BC) and Later (c. 400 BC-AD 43/48) Iron Age. Recent work on the Bayesian chronological modelling of sites in northern Britain (Hamilton 2011) is beginning to combat these problems, with detailed chronologies now being established for sequences extending across the earlier Iron Age plateau and into the later Iron Age (e.g. Broxmouth hillfort in southern Scotland; Hamilton et al. 2013, 646-47). This work is highlighting the need to revisit the interpretation of Iron Age period categorization more generally (Hamilton et al. 2015).

Concerns regarding the viability of radiocarbon dating on the earlier Iron Age plateau have limited the application of the technique on southern British midden sites (Table 1). Of the thirty or so identified sites, only seven have any radiocarbon dates at all, and key sites, such as All Cannings Cross itself, have none. Some sites, such as Whitecross Farm or Wittenham Clumps/Castle Hill, Oxfordshire, have no dates from the midden itself, but rather have results from stratigraphically related deposits. Important sites at Potterne, in Wiltshire, and Runnymede Bridge, in Surrey, were dated before the widespread availability of Accelerator Mass Spectrometry and so the number and quality of samples selected was severely constrained by the quantity of material needed for conventional dating, and the quoted error terms on the available measurements are comparatively large. Interpretation and analysis of the Runnymede sequence occurred before software was available to allow the application of Bayesian statistical modelling, although basic models incorporating the limited data available have been presented for Potterne, Wiltshire (Lawson et al. 2000) and Wittenham Clumps/Castle Hill (Allen et al. 2010). Overall, this radiocarbon dating has contributed little to the debate on the chronology of these midden sites, other than to confirm the suggested dating of $c$. $1000-600 / 500$ BC (although the Area 16 East midden at Runnymede has been interpreted as forming between c. $900-700 \mathrm{cal} \mathrm{BC;}$ Ambers and Leese 1996, 82). Discussion has instead concentrated on the typological associations of the recovered finds.

A small selection of sites demonstrate comparatively long periods of activity which extend into the Iron Age, such as Llanmaes in the Vale of Glamorgan and Worth Mattravers on the Isle of Purbeck. The analysis of Llanmaes is interesting. Based on the material culture and an interpretation of the radiocarbon dates, Gwilt et al. (2016) have argued that the midden deposits here date to the Late Bronze Age/Early Iron Age transition (Llyn Fawr period) and the early part of the succeeding Early Iron Age. The assemblage includes forty complete or 
fragmentary Sompting or Amorican socketed axes (typically Llyn Fawr in date, 800-600 BC), fragments from at least five Class B2 cauldrons (late Llyn Fawr in date, c. 650/625 BC), and some brimless cauldrons and bowls which are typologically Early Iron Age in date (Hallstatt D1, c. 615-530/20 BC; Gwilt et al. 2016; the metalwork periods are based on O'Connor 2007). The absence of any early La Tène metal on the site suggests that metalwork (and probably pottery) deposition into the midden had ceased by c. 500/450 BC (Gwilt pers comm.), however the midden continued to grow throughout the Iron Age, with significant quantities of later Iron Age and Roman pottery also later being incorporated and mixed into the deposit.

Llanmaes is a relatively rare example of a midden site associated with a large assemblage of Llyn Fawr and Early Iron Age metalwork. Most of the midden sites typically produce Ewart Park metalwork assemblages, which date from the tenth to ninth centuries BC (Needham 1996, fig. 1), with a limited selection producing small amounts of Llyn Fawr material (e.g. Potterne) (for an overview, see Needham 2007). Until now, it has been the ceramic assemblages which have provided the most useful framework for dating most of the midden sites. Late Bronze Age pottery assemblages, called post-Deverel-Rimbury (hereafter referred to as PDR) plain wares are dominated by large vessels, such as high-shouldered, thick-walled and straight-sided or barrel shaped vessels, ovoid jars, shouldered jars, often plain and hookrimmed, and smaller flat-topped biconical bowls (Barrett 1980; Morris 2000, 159; Needham 1996, 134). The vessels are occasionally decorated with finger-tip impressions and stab decorations on the rims, and incised and tooled geometric designs occur on the finer fabrics (Barrett 1980, 302-03). Radiocarbon dating of these assemblages is rare (see Morris 2013, 105, table 5.1) and it has been suggested that the main period of their use falls within the tenth and ninth centuries cal BC (Needham 2007; Woodward 2009, 271; Woodward and Jackson 2015, 95). Recent Bayesian analyses of radiocarbon dates associated with PDR plain wares at Huntsman's Quarry in Worcestershire (Bayliss et al. 2015, 14-15) and Cliffs End Farm in Kent (Marshall et al. 2015, 85), however, have demonstrated that they were in circulation from the end of the twelfth to the ninth centuries cal BC. The material from Cliffs End Farm suggests that change is visible within the sequences; simple plain ovoid and hookrimmed and straight-sided jars are more typical of the twelfth and eleventh centuries cal BC assemblages, and shouldered jars, higher numbers of bowls, and a limited range of decoration characterize assemblages dating to the tenth and ninth century cal BC. The material at Huntsman's quarry is early in the tradition, centring on the eleventh century cal BC (Bayliss et al. 2015, 16). Bayesian analysis of radiocarbon dates associated with PDR plain wares from Bestwall Quarry, Dorset, have placed this material as late in the tradition, beginning in 1020 -930 cal BC (95\% probability; start LBA plainware) and ending in 825-750 cal BC (95\% probability; end LBA plainware) (Woodward 2009, 270).

The pottery dating to the Late Bronze Age-Early Iron Age transition is referred to as PDR decorated wares (see Morris 2013, 107-114). These assemblages display a much wider range of vessel forms, such as large carinated and shouldered jars, conical/biconical and shouldered bowls, and cups (Morris 2000, 161-65). Decoration becomes much more elaborate and conspicuous at this time, especially in Wessex. Finger-tip decoration of the rims still occurs, although pots are also commonly decorated with applied cordons and cabling on the rims, and incised lines in concentric circles or rectangular patterns based on chevrons on the shoulders (Barrett 1980, 302-3). This is especially apparent in the regionally distinctive All Cannings Cross wares found in Hampshire and Wiltshire, where decoration is sometimes enhanced with chalk inlay. This ceramic group is named after the pottery assemblage from All Cannings 
Cross (Cunnington 1923) which comprises PDR decorated wares and Early Iron Age wares. They are classified in Cunliffe's (2000, 162-63) and Brown's $(2000,120)$ sequence as Ceramic Phase 1-2 (which is undated), characterized by 'red-finished bowls with furrowed decoration, large jars with zones of incised geometric or impressed decoration, and a coarseware component of shouldered jars with finger-tip/nail or stabbed decoration on the rim and shoulder' (Brown 2000, 120). Some pots are well burnished and others, such as the fineware bowls, are covered with a haematite slip which is burnished to give a reddish brown lustre (Brown 2000, 120), possibly to imitate contemporary Llyn Fawr bronze vessels (Sharples 2010, 176). Pottery assemblages from sites further north (including the Thames Valley) are not as ornately decorated, but the forms and fabrics are also far more diverse in this period (Needham 2007).

Up until now, it has been argued that PDR decorated wares were circulated from the late ninth century $\mathrm{BC} /$ beginning of the eighth century $\mathrm{BC}$, to at least the end of the seventh or the mid-sixth century BC (c. 850/800 to 600/550 BC; e.g. Barrett 1980, 314; Needham 1996, 134; Cunliffe 2000, 162-63), although some specialists have highlighted that the ceramics may well have continued past 600/550 BC (Hill 1995, 9; Needham 2007, 42). Needham and Spence (1997; Needham 1990) have argued that the radiocarbon dates associated with assemblages from Runnymede Bridge and Petters Sports Field in the Thames Valley confirm their inception from the late ninth century or the beginning of the eighth century cal BC (by $c$. 800 cal BC; see also Needham 1996, 134; 2007, 46). The decorated wares from Cliffs End Farm in eastern Kent are more similar to the Wessex assemblages, and are potentially of more relevance to this discussion. They are loosely dated to the eighth and - probably more likely - the seventh centuries cal BC, and include shouldered bowls with diagonal cabling, redfinished bowls, and long-necked and shouldered jars with linear and herringbone decoration (Leivers 2015, 160). They are largely restricted to the upper midden layers from a pit (Pit 2028) located within the northern Late Bronze Age enclosure. The accumulation of these materials is estimated to have stopped in $775-590$ cal BC (95\% probability; end_layer_2_start_1) and probably in 760-685 (68\% probability) (Marshall et al. 2015, 84). The Bayesian modelling also suggested that distinctive traits of decorated wares - such as a combination of neck-cordoned jars, cabled rims, and finger-tip impression in multiple locations - are visible from the beginning of the ninth century cal BC at this site (Marshall et al. 2015, 86). While the patterns observed at Cliffs End Farm need to be verified by similarly robust dating programmes elsewhere, the authors suggest that an early phase of decorated wares may have appeared in the east and coastal areas of southern England by the beginning of the ninth century cal BC (Marshall et al. 2015, 86-87).

The assemblage of PDR decorated wares from East Chisenbury is dominated by long- and short-necked furrowed bowls, and the most complicated decorative motifs occur on the finer bowls, including 'parallel lines, diagonal lines, infilled triangles, bordered zig-zags, split herringbone, swag, and ring and dot designs' (Raymond 2010, 66, fig. 10). There are a large number of decorated coarse wares present in the assemblage, including rare decorated jars which possess horizontal and vertical cordons arranged in a grid-pattern (Raymond 2010, 68, fig. 14). The PDR decorated wares from Potterne (Stratigraphic Zones 10/9-2) include a wide range of typical vessel forms - bowls, jars, and cups — with the assemblage again being dominated by bowls. Biconical bowls are most frequent in the lower layers, peaking at Stratigraphic Zone 7, and long-necked bowls dominate the assemblage in the upper-most layers, peaking in Stratigraphic Zones 4-3 (Morris 2000, 161; Sharples 2010, 320). A diverse range of geometric and circular decorative motifs are present in the assemblage (Morris 2000, 
153, appendix 3). It was noted that some decorative motifs observed in the Potterne assemblage did not occur at All Cannings Cross, and vice versa, and this may have chronological significance (Morris 2000, 153). This interpretation is supported by the presence of Early Iron Age scratch cordoned bowls and La Tène 1 and 2 brooches at All Cannings Cross (Cunnington 1923), which suggests that midden deposition here also continued into the Early Iron Age, similar to Llanmaes.

Due to an observed increase in the numbers of furrowed bowls and the relative percentage of bowls with a haematite finish, Cunliffe (1995, 64-5) split the All Cannings Cross ceramic group into an earlier and a later phase. This division has not been adopted by other specialists but suggests a chronological complexity and longevity to the assemblages that has not been examined in detail (although as noted above, it is hinted at by Morris 2000; see also Marshall et al. 2015). This is an important point to stress, particularly when we consider the proposed dating of the Early Iron Age fineware ceramic series in Wessex. Early Iron Age decorated finewares in the All Cannings Cross tradition - namely the 'scratch cordoned bowls' - are finished with a haematite slip and possess elaborate geometric motifs infilled with white inlay. These distinctive bowls - which are round-bodied and possess a foot-ring base - are traditionally thought to date from the middle of the sixth century cal $\mathrm{BC}$, and on this basis, the complete absence of these ceramics from East Chisenbury and Potterne supported an interpretation that midden deposition ceased around 600 or $550 \mathrm{BC}$ (e.g. McOmish et al. 2010, 83-84). However, the Bayesian modelling of radiocarbon dates from Danebury hillfort in the 1980s suggested a later date for their inception (Buck and Litton 1995). They are associated with Ceramic Phase 3 of the Danebury sequence, which was originally argued to date to c. 470-360 cal BC (Buck and Litton 1995, Table 40; Cunliffe 1995, 18; Cunliffe 2000, 163). These ceramics place the first phase of occupation at many Early Iron Age hillforts in the mid-fifth to mid-fourth centuries cal BC (e.g. Danebury, Quarley Hill, Figsbury, and Woolbury; Cunliffe 2000, 164-66). This dating of the scratch cordoned bowls presented a problem; there was an apparent and rather puzzling gap in the All Cannings Cross ceramic sequence, with PDR decorated wares disappearing by the early or mid-sixth century BC, and scratch cordoned bowls appearing some 100-150 years later (Sharples 2010, 32122). As part of current research revisiting the chronology of the Danebury sequence (https://www2.le.ac.uk/departments/archaeology/research/previous-research-projects/redating-danebury-hillfort), Bayesian chronological modelling is suggesting that an even later date for the inception of these ceramics is possible, thereby extending this gap even further (Haselgrove pers. comm.).

\section{Approach and Objectives of the Dating Project}

As outlined above, East Chisenbury is unusual as the stratigraphy of the midden is well defined because of an interweaving sequence of chalk surfaces and different coloured layers. This provides useful information that can be included in Bayesian chronological models. Bayesian statistics provide a formal and explicit methodology for interpreting radiocarbon dates within their archaeological contexts (Buck et al. 1996). Where we have strong archaeological prior information, such as sequences derived from stratigraphy, the information can be combined with the calibrated radiocarbon dates to produce chronologies that are often both more reliable and more precise (Bayliss et al. 2007) than those that would be otherwise available. The utility of the technique is demonstrated by its increasingly widespread use, particularly for site-based studies (Bayliss 2009). 
Nonetheless, the plateau in the calibration curve in the middle of the first millennium cal BC is the most extreme encountered in the Holocene (Illus. 1), and concerns were expressed about the potential for using Bayesian statistics to provide accurate dates in this period from the early days of the method (Steier and Rom 2000; Steier et al. 2001). Applications that attempt to produce precise chronologies in this period are still rare, and those that exist usually exploit the extremely powerful prior information provided by floating tree-ring series. Some tree-ring sequences extend beyond either the start or the end of the plateau and can thus be fixed against steep sections of the curve (Kuzmin et al. 2004; Quarta et al. 2010), but in other cases, precise dating has been suggested for series that fall entirely within the plateau (Cook et al. 2010; Chochorowski et al. 2014). Research is also underway to improve our understanding of the detailed structure of the calibration curve in this period (Kromer et al. 2010; Suzuki et al. 2010; Taylor and Southon 2013; Jacobsson et al. 2017).

So far, the use of radiocarbon in the British Iron Age has largely been confined to the period after 400 BC (e.g. Hey et al. 1998; Bayliss et al. 2003, 2005; Garrow et al. 2009; Outram et al. 2010; Hamilton 2011; Jay et al. 2012; Armit et al. 2013). Exceptionally, however, the long stratigraphic sequence through the inner ditch west at Broxmouth hillfort begins on the plateau before extending into the Middle Iron Age. For the first time, this has enabled radiocarbon dating to provide comparatively precise date estimates for archaeological events and phases that occurred within the Early Iron Age (for example, phase 1 at Broxmouth began in 715-550 cal BC (95\% probability; start: Phase 1; Hamilton et al. 2013, figs 9.3, 9.12), probably in 640-570 cal BC (68\% probability), and phase 2 began in 515-415 cal BC (95\% probability; start: Phase 2; Hamilton et al. 2013, figs 9.3, 9.12), probably in 530-490 cal BC (68\% probability)).

Clearly, sequence is critical in constructing precise chronologies in this period, allowing an ordered suite of radiocarbon measurements to be matched to the detailed structure of the plateau. Tree-rings, where not only the sequence but the calendar separation of the samples is known, provide sufficiently powerful information for Bayesian modelling to provide precise chronologies within, as well as across the ends, of the plateau. Dating East Chisenbury is the next step in determining whether the weaker, ordered but not spaced, sequences of dates from stratigraphic sequences will be able to provide dating of sufficient precision to be useful in this period.

East Chisenbury meets the critical requirement for providing precise chronologies in the earlier Iron Age by providing the clear stratigraphic sequence that may allow the Bayesian model to overcome the problem of the first millennium plateau. This site represents one of a handful of sites in southern Britain which has the necessary technical features to make such an application feasible. It is also a more ambitious target than Broxmouth, since it is expected that nearly the entire sequence from East Chisenbury will fall on the plateau. Beyond its interest as a technical case-study, precise dating will also address a range of important questions:

- What is the chronology of the material accumulations? Are there any major disruptions in the deposition of material, both horizontally and vertically within the sequences? Are there any apparent differences in the chronology of deposition between the different excavation trenches? 
- To what extent do the animal bone and pottery assemblages demonstrate chronological integrity and support the stratigraphy? This question is integral to understanding formation processes, discard rates, and the refuse-cycles of materials.

- Will the dating of pottery residues from specific vessel forms substantiate or undermine current understanding of the post-Deverel-Rimbury ceramic sequence in Wessex?

\section{The excavated sequence at East Chisenbury}

Two small trial trenches were opened at East Chisenbury in the 1990s. Trench A was $2 \mathrm{~m}$ by $1 \mathrm{~m}$ and located in the centre of the mound. The midden sequence was $1.5 \mathrm{~m}$ deep in this area, although due to the quantity of material present, only one square-metre of the deposit was fully excavated (McOmish et al. 2010, 50, fig. 4). The sequence begins with a ploughsoil accumulation (context 11) and this is covered by seven discrete midden layers (see Illus. 2). Concentrations of pottery and objects were observed in particular layers, such as contexts 9-6 and 4-2, and these were separated by some thin and ephemeral spreads of chalk (McOmish et al. 2010, 50). Trench B was $3 \mathrm{~m}$ by $2 \mathrm{~m}$, and located on the southern perimeter of the mound (McOmish et al. 2010, 50, fig. 4); here, the deposits reached a depth of $1.67 \mathrm{~m}$, and postholes, shallow pits, and a hearth were sealed by the midden (see Illus. 3; see also McOmish et al. 2010, fig. 6). The midden soils in this trench consisted of a basal ploughsoil (context 35), overlain by differently coloured midden layers; sometimes orange in colour and rich in bone deposits (e.g. contexts 4 and 19), or greyish or brown in colour (e.g. contexts 15 and 11; McOmish et al. 2010, 50). Importantly, the midden layers in this trench were separated by at least eighteen chalk deposits: compacted layers that varied in size and thickness. They differ from the ephemeral spreads of chalk in Trench A, and some were very substantial (e.g. contexts 21, 16, and 14). Some are linked with depositional events; the three largest groups of pottery were deposited either immediately before or during the creation of chalk surfaces (e.g. 1772 sherds were sealed by a chalk floor, context 6; 904 sherds came from a compacted chalk deposit, context 18; and 1012 sherds came from another compacted chalk deposit, context 24; Raymond 2010, 69).

The initial soil accumulations in both trenches need to be discussed briefly. These were characterized as ploughsoil horizons and as old land-surfaces by the excavators (McOmish et al. 2010, 50, tables 1-2). In Trench A, the ploughsoil (context 11) consisted of a dark grey clay, while a dark sandy layer makes up the ploughsoil in Trench B (context 35). The pottery and animal bone assemblages from these two layers were substantial and the assemblages weighed more than most assemblages from individual layers in the upper midden (see Illus. 4). As such, these primary ploughsoil layers should be classed as the beginning to the 'midden' sequence. This is not unusual; lighter soil accumulations rich in finds were identified at the base of the dark earths at Potterne (e.g. the 'Terrace soils'; Macphail 2000, 59), Whitchurch (Waddington and Sharples 2011, 63), Whittenham Clumps (Hingley 197980, 25) and Woodeaton (Harding 1987, 29-31). These layers were heavily mixed with the underlying natural soils, which reflect ploughing activities, and they highlight the presence of an earlier and more protracted phase to the beginnings of midden accumulation on many sites.

At East Chisenbury the basal ploughsoil in Trench B (context 35) comprises both PDR plain and decorated wares, and a tanged chisel or knife was also retrieved which is probably Middle or Late Bronze Age in date (Barber 2010, 80). The mixed character of this assemblage suggests that the horizon formed over a relatively long period of time. In contrast, 
the overlying layers only produced PDR decorated wares. A different situation is present in Trench A. Only PDR decorated wares were present, including the basal ploughsoil (context 11), suggesting a later date for its formation. This interpretation is supported by the recovery of a possible Llyn Fawr Sompting socketed axe fragment from the primary layer (Barber 2010, 78-80). The excavators, therefore, argued that the initial occupation in Trench A occurred no earlier than $800 \mathrm{BC}$, but they also suggest that the assemblages from the ploughsoil in Trench B represent mixed deposits of differing dates that were laid down at around the same time (McOmish et al. 2010, 83, 87).

Both trenches produced large quantities of pottery and animal bones. The animal bone assemblage is dominated by sheep (Serjeantson et al. 2010), and this is reflected in the soil micromorphology which contains large numbers of spherulites, interpreted by Macphail (2010) as representing burnt sheep coprolites. In total, 77,237 g of pottery and 26,152 g of animal bones were retrieved from these small excavation areas. Trench B produced the majority of the pottery and animal bone assemblage from this site $(65,234 \mathrm{~g}$ of pottery and $20,944 \mathrm{~g}$ of animal bones; Waddington 2009). A large proportion of the sherds in the assemblage are fresh; some sherds join and some have food residues preserved on the interiors of the vessels. The presence of adjoining potsherds within different layers, such as within contexts 6 and 18 in Trench B, demonstrate complex formation processes and the repeated mixing of some midden residues prior to their final deposition (Raymond 2010).

\section{Methodology}

Twenty-eight samples of animal bones and pottery residues were dated at the Oxford Radiocarbon Accelerator Unit (ORAU) through two ORADS proposals as part of two AHRC-funded doctoral projects (Waddington 2009; Madgwick 2011a). The majority (twenty-one in total) were chosen from Trench B (Table 2), as this had the clearest stratigraphy and it produced the best quality samples (Illus. 3). Seven animal bone samples were dated from the basal ploughsoil horizon (context 35). This layer is sealed by a secondary cultivation soil (context 24), which is in turn sealed by a chalk surface (contexts 21 and 22). Overlying this chalk surface is the main phase of the undisturbed midden layers, beginning with context 20 and ending with context 4; we dated samples from contexts 20 (one animal bone sample), 18 (three animal bone samples), 7 (one animal bone sample), 6 (four pottery residues and two animal bone samples), and 4 (two pottery residues and one animal bone sample). Context 4 is protected from the upper-most layers of the midden by substantial dumps of chalk.

The stratigraphy in Trench A was less distinct and the area was less productive in dateable material (Illus. 2); as such, we were only able to retrieve seven samples. Three samples were dated from the primary ploughsoil horizon (context 11; one pottery residue and two animal bone samples). Overlying this is the main midden sequence, beginning with contexts 10 and ending with context 2. Only the lower and middle layers were selected for dating: context 10 (one pottery residue); context 8 (two animal bone samples); and context 6 (one animal bone sample).

The sampling strategy outlined above was designed to maximise the depth of the stratigraphic sequence that could be included in the model. Stratigraphy, of course, provides relative dating for the sequence of contexts recorded during excavation. Radiocarbon dating, however, measures the radiocarbon content of samples, and so it is only valid to constrain the calibration of the measurements from those samples by the relative ordering provided by 
stratigraphy, as long as the samples were freshly deposited in the context from which they were recovered. This taphonomic relationship was assessed following the principles outlined in Bayliss et al. (2011). In descending order of reliability, the dated material comprised:

1. articulating groups of animal bone, or juvenile animal bones with refitting unfused epiphyses $(n=10)$;

2. carbonised residues on the interior of groups of refitting pottery sherds $(n=6)$;

3. a pair of sheep/goat mandibles from the same individual $(\mathrm{n}=1)$;

4. carbonised residues on the interior surface on unabraded single pottery sherds $(n=2)$;

5. disarticulated animal bones, interpreted as primary deposition because of the unabraded nature of the material/ lack of taphonomic modification (e.g. survival of sharp, fragile edges $)(n=9)$.

\section{Samples of charred food residues}

Sample selection was constrained by the quality of pottery assemblage. In Trench B, only contexts 6 and 4 in the upper midden sequence produced suitable charred food residue samples for dating, and only contexts 11 and 10 in the lower midden sequence in Trench A produced suitable samples (see criteria 2 and 4, above; Table 2). No complete vessel was reconstructed in the pottery assemblage (Raymond 2010,69), but a large proportion of a decorated jar with food residues on the interior was reconstructed from context 6 in Trench B, and this was selected for dating (OxA-20216; Illus. 5). Another sample came from the reconstruction of a third of a fineware bowl from context 11 in Trench A (OxA-20217; Illus. 6). The remaining samples consisted of food residues on the interior of sherds deriving from an everted coarse-ware jar with fingertip impressions on the shoulder and rim (OxA-26114); a plain jar (OxA-20275); a decorated jar (OxA-20267); a burnished bowl (OxA-26040); a fineware bowl (OxA-26115); and a fine shouldered jar with fingertip impressions (OxA26116-17).

\section{Samples of animal bones}

A total of 1124 identifiable specimens were recovered from Trench B and 323 from Trench A (Serjeantson et al. 2010). However, as preservation was mixed, suitable specimens for dating were not common. Where possible, strict criteria were enforced for the selection of faunal remains to ensure, as far as is possible, that samples represented primary deposits. Priority was given to three sample categories. Articulating elements were targeted, as it is unlikely that they would remain in the same deposit if substantial reworking had taken place. For the same reasons, unfused epiphyses that were associated with the adjoining metaphysis were also sampled. Neonatal and perinatal bones that were complete or near complete (excluding epiphyses) were also targeted, as these bones are highly susceptible to destruction and very unlikely to survive if redeposited. Very few neonatal/perinatal bones survive in good condition in middens, as they degrade very rapidly and most deposits will be subject to subaerial exposure for at least a short period. Some neonatal specimens were recovered from target contexts, but all suffered some erosion or fragmentation and therefore articulating elements or epiphyses were prioritized. Eleven of the twenty bone samples fitted these principal criteria (see Table 2). 
Some contexts produced insufficient samples that fitted the aforementioned criteria and therefore value judgements had to be made on the suitability of other specimens. Unfused epiphyses and metaphyses were accepted if the fusion surface appeared fresh and free from erosion. Four samples that fitted this criterion were analysed. Fusion surfaces are porous and easily degraded. Therefore if they are well-preserved it is likely that they were protected by the fusing element, which may not have been recovered in excavation. In any case it is highly unlikely that the deposit has been substantially reworked, due to the clear stratigraphy and the good preservation of the porous fusion surface. In five instances, complete or near-complete bones with immaculate surface preservation, free from weathering and scavenger damage, were also sampled. For near-complete bones, fracture surfaces were scrutinised to ensure that the break occurred when the bone was fresh and that the surface had not degraded substantially thereafter. It cannot be guaranteed that samples that fit these secondary criteria were primary depositions, but on the balance of probability it is considered highly likely. Middens accumulate as surface deposits and as such are highly susceptible to trampling, weathering, and scavenger damage, all of which act to modify and fragment assemblages. Although accumulation can be rapid (Madgwick and Mulville 2015b), faunal assemblages from middens tend to be heavily modified and highly fragmented (Madgwick 2016) and therefore near-complete bones with excellent surface preservation are highly likely to be primary deposits.

\section{Chronological modelling}

Full details of the dated samples, conventional radiocarbon ages, and stable isotope values are provided in Table 2. All samples were pre-treated, graphitized, and dated by AMS at the Oxford Radiocarbon Accelerator Unit between 2008 and 2012 (Brock et al. 2010; Dee and Bronk Ramsey 2000; Bronk Ramsey et al. 2004). Two pairs of replicate measurements are available, both of which are statistically consistent (Table 2). Weighted means of these results have been taken before calibration (Ward and Wilson 1978).

The Bayesian chronological modelling, which combines these radiocarbon data with the excavated sequence, has been undertaken using the program OxCal v4.2 (Bronk Ramsey 2009) and the calibration dataset of Reimer et al. (2013). The algorithms used are defined exactly by the brackets and OxCal keywords on the left-hand side of Illus. 7. Those for the chronological models relating to comparable sites are defined in supplementary information Figures S1-S2 and S5-S9 (http://c14.arch.ox.ac.uk/). The posterior density estimates output by the model are shown in black, with the unconstrained calibrated radiocarbon dates shown in outline. The other distributions correspond to aspects of the model. For example, the distribution 'start basal midden' (Illus. 7) is the posterior density estimate for the time when the midden at the base of the sequence at East Chisenbury began. In the text and tables, the Highest Posterior Density intervals of the posterior density estimates are given in italics. The model for the chronology of the midden deposits at East Chisenbury is shown in Illus. 7. It has good overall agreement (Amodel: 71; Bronk Ramsey 1995, 429; 2009, 356-7).

Seven animal bone samples, four of them of articulating bone groups, have been dated from the basal ploughsoil deposit (35) in Trench B. This deposit produced a mixture of PDR plain and decorated wares. It may be equivalent to the basal ploughsoil deposit (11) in Trench A, from which a possible Sompting-type axehead dating to the Llyn Fawr period was retrieved and three samples have been dated. Unlike the ploughsoil in Trench B, however, this layer 
only produced PDR decorated wares, suggesting that it began to accumulate later than Trench B. One of the samples dated from this layer, a cattle phalanx with refitting epiphysis, is clearly intrusive and has been excluded from the model (OxA-20274; Illus. 7).

This basal accumulation began in cal BC 1020-855 (95\% probability; start basal midden; Illus. 7), probably in cal BC 975-890 (68\% probability). It ended in cal BC 795-700 (95\% probability; end basal midden; Illus. 7), probably in cal BC 790-745 (68\% probability). By calculating the difference between these two dates, we can estimate that this period of occupation endured for 70-290 years (95\% probability; use basal midden; Illus. 8), probably for $120-225$ years (68\% probability). It is possible that the activity in Trench A continued slightly later than the activity in Trench B. Two sequences of samples are available from the overlying Late Bronze Age-Early Iron Age (hereafter referred to as LBA/EIA) midden deposit. In Trench A, four samples from the lower part of the midden, from contexts 10, 8 , and 6, produced dates which are in good agreement with the stratigraphic sequence. A series of 14 samples through all but the uppermost part of the LBA/EIA midden in Trench B (contexts 20,18, 7, 6, and 4) also show good agreement with the stratigraphy, although two samples (OxA-24063 and OxA-20216; Illus. 7) may be residual from the underlying basal midden, which is somewhat surprising. OxA-24063 was on articulating first and second sheep/goat phalanges from context 18, one of which is fused and the other in the process of fusing. The fit was convincing, but is possible that the re-articulation was in error, especially as the sample derived from a large assemblage from what may have been a large, genetically homogenous, flock. However, given the quality of the sample, this seems unlikely; it is possible that the pair of bones was moved together into context 18 from a pre-existing midden located elsewhere (see below), or from an underlying layer. The latter interpretation is rendered plausible by the fact that context 18 lies physically above ploughsoil context 24 over much of its extent. The early date produced by OxA-20216 is also surprising, since this was from an extensive charred residue on the interior of a group of refitting sherds representing most of a decorated vessel found in context 4 . It is hard to see how so much of a vessel could have been redeposited over a vertical distance of at least $0.6 \mathrm{~m}$, or from another location, and still remained so intact. In this case, perhaps, it is the measurement on the residue that is anomalous (see Bayliss et al. 2011, 56).

Removing these two samples as misfits from the analysis, the chronological modelling suggests that the LBA/EIA midden began to accumulate in cal BC 750-565 (95\% probability; start LBA/EIA; Illus. 7), probably in cal BC 720-690 (14\% probability) or cal BC 685-615 (47\% probability) or cal BC 600-580 (7\% probability). This midden stopped accumulating in cal BC 500-355 (95\% probability; end LBA/EIA; Illus. 7), probably in cal $B C$ 455-385 (68\% probability). Overall, it was used for $90-365$ years (95\% probability; use LBA/EIA; Illus. 8), probably for 170-320 years (68\% probability). There was an interval of 2-190 years (95\% probability; cultivation episode; Illus. 8), probably 30-145 years (68\% probability) between the end of the basal midden (ploughsoil) and the beginning of the LBA/EIA midden. The site was probably cultivated during this time.

\section{Sensitivity analysis}

Given the challenges of producing robust and accurate dating on the 'Halstatt' plateau, we now assess the accuracy of the chronology just proposed. The dating of the basal midden (ploughsoil) seems to span a longer period than previously envisaged. Our date estimate for 
the end of this basal accumulation (cal BC 795-700 at 95\% probability; cal BC 790-745 at $68 \%$ probability; end basal midden; Illus. 7) is entirely compatible with current dating for the Llyn Fawr metalwork from Trench A (context 11), and the geometric motifs on PDR decorated wares from Trench B (context 35) and Trench A (context 11). The deposit in Trench B was certainly accumulating earlier, however, very probably for much of the ninth century cal BC, and probably for the last decades of the tenth century, too (start basal midden; Illus. 7). This accords well with current interpretations of the chronology of PDR plain wares (see above). The presence of PDR decorated wares in this horizon does not necessitate re-dating of these finds since they may have been deposited during the latter part of this period of occupation. The date estimate for the end of the accumulation of this horizon confirms that PDR decorated wares were in circulation by at least the eighth-century cal BC, and probably by the ninth century cal. BC.

Radiocarbon dates from sixteen samples are included in the model for the chronology of the LBA/EIA midden (Illus. 7). The samples all derive from the sequence which is associated with PDR decorated wares. Plotting the posterior distributions provided by the model for these samples against the radiocarbon calibration curve (Illus. 9) demonstrates that the use of this midden does not span the entire plateau. Our estimate for the start of the accumulation is imprecise, but the balance of probability suggests that it began in the mid-seventh century cal BC (start LBA/EIA; Illus. 7). There is little probability that any of the radiocarbon dates from this midden actually date to the first century of the plateau (Illus. 9). The precision of this estimate could be improved by dating more samples from the lower midden layers in Trench B (contexts 26, 20, 18, and 15). We have no artefactual dating of sufficient precision to aid us in assessing the reliability of this modelled estimate for the start of the LBA/EIA midden.

Comparison of this estimate with that for the end of the underlying basal midden (ploughsoil), however, does suggest that there was a gap between them of around a century (cultivation episode; Illus. 8). Given the potential difference between the dates for the end of the basal midden in Trenches $\mathrm{A}$ and $\mathrm{B}$, it is possible that the occupation underlying the LBA/EIA midden continued longer elsewhere on the site, but current evidence suggests that there was a gap between the two episodes of occupation. This is compatible with the suggestion made by the excavation team that contexts 35 and 26 in Trench B, and context 11 in Trench A, may represent ploughsoils (McOmish et al. 2010, Table 1).

Our estimate for the date when the LBA/EIA midden stopped accumulating (cal BC 500-355 at $95 \%$ probability; cal BC 455-385 at 68\% probability; end LBA/EIA; Illus. 7) does coincide with the end of the calibration plateau (Illus. 9). It is apparent, however, that the radiocarbon dates from the latest midden deposits (context 4 in Trench B) - which include dated food residues from a fine-ware burnished bowl and a decorated jar - fall into the fifth century cal $\mathrm{BC}$, and they have not been constrained by the model onto the end of the plateau (Illus. 7 and 9). The chronological model shown in Illus. 7 estimates that it is $99 \%$ probable that accumulation of the LBA/EIA midden ended after $500 \mathrm{cal}$ BC.

We were initially concerned that our model may be stretching the chronology of the LBA/EIA midden at East Chisenbury to fill the length of the calibration plateau. To investigate this possibility, we constructed a series of ten simulation models. These are all of the form of the LBA/EIA midden component of the model shown in Illus. 7. Simulated measurements run from BC 660 (the median of the start LBA/EIA parameter in that model) to BC 422 (the median of the end LBA/EIA parameter). The error terms on the simulated 
measurements are those quoted for the actual results reported for this study. Consequently, this simulation incorporates the actual prior archaeological information that we have for the dated samples from East Chisenbury, along with the same quantity and quality of data.

The model incorporating these simulated dates is shown in Illus. 10. Clearly, both the start and end parameters include the actual dates input into the simulation (BC 660 and BC 442, respectively). In fact, these dates are included in the Highest Posterior Density intervals for the relevant parameters at both $95 \%$ and $68 \%$ probability. To investigate the reliability of the end parameter, this model was then re-run with the actual end date input into the simulation and set twenty years earlier each time (i.e., with models running from BC 660-442, BC 660462, etc., to BC 660-602). The end parameters from each model are shown in Illus. 11. In all cases, the posterior estimates are compatible with the end dates input into the simulations. Indeed, these dates are all included in the Highest Posterior Density intervals for the relevant parameter at $95 \%$ probability (and eight are at $68 \%$ probability). This is in line with statistical expectation.

We are therefore confident that our date estimates for the LBA/EIA midden and its associated PDR decorated wares at East Chisenbury are reliable, and not an artefact of the radiocarbon calibration curve or the methodology that we have used. The quality and quantity of prior information and radiocarbon dates available to us is demonstrably sufficient to distinguish between an ending for the midden in the mid-fifth century cal BC (as suggested by our study) and an ending at the beginning or middle of the sixth century cal BC (as suggested by existing understanding of the regional ceramic sequence).

\section{Radiocarbon chronologies for other midden sites}

As stated near the beginning of this article, concerns about the difficulties of producing precise chronologies on the earlier Iron Age plateau have discouraged the application of radiocarbon dating on the southern British midden sites. Table 1 provides details of ninetytwo radiocarbon determinations from seven such sites, but only twenty-four of these derive directly from the LBA/EIA middens themselves. The remaining measurements were made on samples from earlier or later activity on the sites, some of which provide limiting data for the chronology of the middens. This section discusses the dating evidence and presents chronological models for the seven midden sites for which radiocarbon dates are currently available. Only the well-published and well-dated sequence at Runnymede Bridge bears comparison with East Chisenbury. There are strong technical grounds for caution when interpreting the existing radiocarbon measurements from Potterne, only limiting data from deposits stratigraphically related to the middens are available from Whitecross Farm and Wittenham Clumps/Castle Hill, and further post-excavation analysis is underway on the sequences at Eldon's Seat, Llanmaes, and Worth Matravers. The models presented here, particularly for the latter three sites, must thus be regarded with some caution.

As described by Allen (2000, 40-1), interpretation of the radiocarbon dates from Potterne is hampered by the uncertain taphonomy of the dated material, the potential for charcoal fragments of diverse ages to be included in the bulk samples needed for conventional dating, and the potential for old-wood offsets. The published interpretation proposes that the midden accumulated between the beginning of the tenth century and the end of the sixth century cal BC (Lawson 2000). This is compatible with the results of the chronological model illustrated 
in Figure S1 (which interprets the samples from Stratigraphic Unit 11 as potentially containing a component of reworked charcoal from the underlying settlement, but assumes that the majority of the charcoal in the samples from Units 7 and 4 was short-lived). It is also supported by the presence of Ewart Park bronzes which occur in the lowest layers of the midden (Stratigraphic Units 10-7; dating from the tenth to ninth centuries BC), and Llyn Fawr metalwork which is present in the uppermost layers (Stratigraphic Zones 6-4; Gingell et al. 2000, 193). The pottery is also well-stratified: the earliest layers contain post-DeverelRimbury plain wares, while the main phase of the midden is associated with post-DeverelRimbury decorated wares (Morris 2000, 161; Stratigraphic Units 10/9 to 4). Whilst the radiocarbon dates from the uppermost layers could allow a later ending, deposition at Potterne has been interpreted as ending during the sixth century BC because of the absence of Early Iron Age scratch cordoned bowls from the uppermost layers of the midden.

Forty-nine radiocarbon measurements in total are now available from Bronze Age activity at Runnymede Bridge, of which eleven probably relate to the middens. Figure S2 presents a chronological model for Late Bronze Age activity at Runnymede, combining these radiocarbon dates with the stratigraphic sequences for Area 6 (Needham 1991, fig. 33) and Area 16 East (Needham and Spence 1996, fig. 8). This model suggests that overall Bronze Age occupation at Runnymede was relatively brief, lasting 1-130 years (95\% probability; use Runnymede; Fig. S3), probably for 50-100 years (68\% probability). Waterfront 1 was constructed in 865-810 cal BC (95\% probability; waterfront 1 (C/D); Fig. S2), probably in $850-825$ cal $B C$ ( $68 \%$ probability). After a brief period of use probably spanning only a decade or two (use waterfront 1; Fig. S3), the waterfront was reconstructed in 845-800 cal BC (95\% probability; waterfront 2 (E); Fig. S2), probably in 830-805 cal BC $(68 \%$ probability). This settlement was overlain in some places by midden deposits (Needham 1991, 345; Needham and Spence 1996, 17). The $0.5 \mathrm{~m}$ of midden in Area 16 East accumulated from 870-805 cal BC (95\% probability; start Runnymede A16; Fig. S2), probably from $850-820$ cal BC (68\% probability) to $795-745$ cal BC (95\% probability; end Runnymede A16; Fig. S2), probably to 790-765 cal BC (68\% probability). That in the Riverside Zone accumulated from $870-805$ cal BC (95\% probability; start Runnymede RZ; Fig. S2) probably from $850-815$ cal BC (68\% probability) to $845-755$ cal BC (95\% probability; end Runnymede RZ; Fig S2), probably to 820-775 cal BC (68\% probability). Deposition in both areas probably began shortly after the settlement was founded, and continued during the period when the waterfronts and associated settlement were in use (Fig. S4). The apparent succession between settlement and midden was probably only local, with midden accumulating in areas away from contemporary settlement.

Published radiocarbon dates from Whitecross Farm are from the settlement which underlay the midden there. The estimated date for the end of this settlement thus provides a terminus post quem for the start of midden formation of 920-720 cal BC $(95 \%$ probability; end Whitecross Farm LBA settlement; Fig. S5), probably of 890-800 cal BC (68\% probability). At Wittenham Clumps/Castle Hill, the LBA/EIA midden accumulated within the upper part of a LBA enclosure. Radiocarbon dates on material from the lower fills of this enclosure therefore provide a terminus post quem for its deposition, and a series of radiocarbon dates associated with Middle Iron Age (MIA) ceramics presumably post-date it (although the midden and the MIA features are not stratigraphically related). The radiocarbon dates do no more than confirm that the midden accumulated sometime between $c .900 \mathrm{cal} \mathrm{BC}$ and $c .400$ cal BC (Fig. S6). Pending full publication of the dating programme, the interpretation of the suite of radiocarbon dates from Eldon's Seat (Table 1) is problematic. These have poor 
agreement (Amodel: 0; model not shown) with the periodisation for the site suggested by Cunliffe and Phillpson (1968, table A). If, however, the dates are modelled following the ceramic associations provided by Ambers and Bowman (1999), and BM-3063 is interpreted as containing a component of reworked bone, then the model has good overall agreement (Amodel: 63; Fig. S7). In this reading, it is possible that BM-3051 may be contemporary with midden formation, although this must be considered highly uncertain pending further information.

Nine radiocarbon measurements have so far been published on material from recent work at Llanmaes (Gwilt et al. 2006; Gwilt et al. 2016; Gwilt and Lodwick 2008; Table 1), although a more extensive programme of radiocarbon dating is currently well underway (Gwilt pers comm.). A provisional model of the published dates is presented in Figure S8, which assumes continuity of human activity on the site and incorporates the recorded stratigraphic sequences between the midden and underlying settlement, and between contexts within the midden itself. This model has good overall agreement (Amodel: 105; Fig. S8), and estimates that the midden accumulated from 740-465 cal BC (95\% probability; start Llanmaes midden; Fig S8), probably from $645-505$ cal BC (68\% probability), until 150 cal BC-370 cal AD $(95 \%$ probability; end Llanmaes midden; Fig. S8), probably until 90 cal BC-110 cal AD (68\% probability). Given the importance of the large metalwork assemblage discussed above, Figure 12 presents the typological analysis of the metalwork alongside the modelled published radiocarbon dates. The evidence reveals that the main midden sequence may have been initiated in the mid-seventh century cal BC and towards the end of the LBA/EIA transition, but that parts of the midden contains metalwork which also dates to the sixth and fifth centuries cal BC (Early Iron Age). This compares well with the sequence that we have identified at East Chisenbury. The sequence at Llanmaes differs in that midden deposits and faunal remains continue to be deposited throughout much of the Iron Age and into the Romano-British period, a pattern which is confirmed by the radiocarbon dates (Gwilt et al. 2006; 2016). Whilst there is a hiatus in metalwork and pottery deposition in the later Early Iron Age and during the Middle Iron Age at Llanmaes, Late Iron Age and Romano-British pottery had been visibly trampled into the earlier midden accumulations (Gwilt et al. 2006; 2016).

Limited information is also currently available about the sequence of deposits recovered at Worth Matravers, although the two radiocarbon dates on short-lived samples that are available suggest that the $0.3 \mathrm{~m}$ of midden there accumulated from $745-515 \mathrm{cal} \mathrm{BC}(95 \%$ probability; first WM midden; Fig S9), probably from 650-540 cal BC (68\% probability), until 655-410 cal BC (95\% probability; last WM midden; Fig S9), probably until 615-505 cal $B C(65 \%$ probability) or 500-485 cal BC (3\% probability). These date estimates appear compatible with the dating proposed for an unused, Armorican, copper-alloy socketed palstave axe and a fragmentary Polish glass finger ring recovered from the midden and related deposits (Ladle forthcoming). This dating for an assemblage of pottery in the 'All Canning's Cross' tradition is also compatible with that suggested here for the material from East Chisenbury.

A summary illustration showing the period of use of middens at the seven sites for which we have direct or indirect radiocarbon dating for their chronologies is presented in Illus. 12.

\section{Discussion}




\section{Histories of deposition at East Chisenbury}

The results have changed the interpretations regarding the formation of the midden at East Chisenbury. The excavators put forward a perfectly reasonable hypothesis that the midden mostly comprised of secondary deposits that accumulated in as little as a century (see McOmish et al. 2010, 92). The Bayesian modelling suggests a much longer duration for the formation of the mound. There is clear evidence for a primary Late Bronze Age ploughsoil/midden horizon, mainly dating to between the late tenth and early eight centuries cal BC (Illus. 7). There then appears to have been a small gap in occupation, perhaps for a century or so (Illus. 8), before the next phase of midden deposition. However, the site was not necessarily abandoned, with cultivation presumably continuing. The main phase of the LBA/EIA midden in both trenches probably began sometime in the mid-seventh century cal $\mathrm{BC}$, with the final midden layers in Trench B being laid down in the fifth century cal BC. We are therefore probably looking at a sequence of occupation that extended over more than fivehundred years, even though the main bulk of the midden appears to have been laid down over a two-hundred-year period, between the mid-seventh and mid-fifth centuries cal BC. So, while the original time estimates for the accumulation rates of the bulk of the midden sequence has not dramatically changed, the time-period for its deposition has.

The primary midden activities on the site were evidently of a much more protracted nature than has originally been argued. This reveals that the scale of consumption events at East Chisenbury in the later tenth, ninth and earliest eighth centuries cal BC was considerably smaller than those occurring on the site between the mid-seventh and mid-fifth centuries cal $\mathrm{BC}$, when deposition dramatically increased. This matches patterns at nearby Potterne: targeted taphonomic analysis of faunal material indicates that the basal deposits in this midden were characterized by a more gradual period of accumulation followed by a hiatus and then an intense build-up of material (Madgwick and Mulville 2015b).

The analysis has also confirmed the chronological integrity of the midden sequence. The majority of dates in the sequence showed good agreement with the stratigraphy, although as outlined above, two dates from samples from the main midden sequence in Trench B were out of alignment with samples from the same contexts (OxA-24063, context 18; OxA-20216, context 4). The dates from these samples were too early, and whilst possible explanations for these anomalies are offered above, it is worth reconsidering them again alongside a consideration of the pottery analysis. One suggestion is that the sample from context 18 represents residual material from the underlying ploughsoil, and another proposes that both samples represent secondary deposits deriving from historic midden layers from another part of the site or from an external settlement. The latter suggestion would support the interpretation of the pottery assemblage from Trench B (Raymond 2010). Raymond highlighted that joining 'sherds from a number of vessels unite contexts 4-24' $(2010,69)$. Occasionally, large, fresh sherds with preserved food residues were found to join similarly fresh sherds retrieved from other contexts in the midden sequence. This was seen to be a result of complex depositional processes, which involved the secondary deposition of material which had originally been deposited (and protected) on another part of the mound (Raymond 2010, 69). Thus, the anomalous dates from the samples discussed above do potentially provide additional supporting evidence that some of the materials making up the mound consist of secondary deposits.

\section{A re-consideration of the monument sequence in Wessex}


On the basis of the results, and the new end-date proposed for midden accumulation at East Chisenbury in the mid-fifth century BC, it is necessary to briefly re-examine the monument sequence in Wessex, which has traditionally regarded midden sites as terminating $c .600 / 550$ $\mathrm{BC}$ and Early Iron Age hillforts being constructed after that time. The latter monuments are typically dated from c. 550 or 500 BC (e.g. Danebury Early Period, c. 550-450 BC; Cunliffe 2000, 167, fig. 4.21; see also Sharples 2010, 72). While midden deposits accumulated on top of the Late Bronze Age hilltop enclosure of Balksbury Camp in Hampshire (Ellis and Rawlings 2001; Wainwright and Davies 1995), midden sites in Wessex have not been thought to overlap in time with Early Iron Age hillforts in the area.

Our understanding of Wessex hillforts is well-established and detailed due to the number and quality of the excavations and the presence of large dateable pottery assemblages. There is considerable variability in the nature of the occupation evidence and it is likely that a variety of activities were undertaken. Sites like Danebury and Winklebury contain roundhouses and significant numbers of grain storage pits and raised granaries, but others such as Woolbury, Bury Hill 1, and Quarley Hill produce very little evidence for internal occupation (Cunliffe 2000, 166). However, as a group, the sites possess many shared characteristics: they are typically around 5 ha in size, enclosed by a single monumental rampart and ditch, and with two opposing entrances (Cunliffe 2000, fig. 4.20).

The chronological sequence for Early Iron Age hillforts in the Danebury Environs area in Hampshire provides the necessary detail for this analysis. Significantly, nearly all of the excavated Early Iron Age hillforts are associated with scratch cordoned bowls which belong to Ceramic Phase 3 of the Danebury sequence (see above), and so the main phase of Early Iron Age hillfort construction belongs to the period directly after East Chisenbury. However, a few hillforts have produced early occupation sequences associated with PDR decorated wares (Cunliffe 2000, 163-66). At Quarley Hill, the western rampart sealed midden deposits rich in PDR decorated wares (Hingley 1979-80; McOmish 1996, 74). This might suggest an earlier settlement or a protracted phase of boundary construction, with the accumulations of midden being used to delineate the boundary before the monumental acts of rampart construction took place in late fifth or early fourth century BC. Hingley (1979-80) has also suggested that dark earths, rich in PDR decorated wares, accumulated outside the hillfort of Winklebury. The hillfort was associated with PDR decorated wares as well as scratch cordoned bowls (Ceramic Phase 2-3), and aside from a handful of roundhouses, it produced a large number of raised granaries and pits for grain storage (Smith 1977). It is possible, therefore, that some overlap exists between the demise of midden sites and the development of some hillforts proper.

If we accept the possibility that some midden sites and Early Iron Age hillforts were contemporary, even for a very restricted period of time, then how can we begin to understand the different roles that these monuments played in Wessex in the mid-first millennium BC? Unlike midden sites, hillforts were a focus for communal acts of boundary construction which required enormous amounts of time, effort, and resources (Sharples 2010). This became a key strategy that communities adopted in light of the demise of bronze, with gift-exchange relationships now being focussed around human labour, raw materials for boundary construction, and food for the accompanying festivals (Sharples 2007). These were settlements, but the main roles of some, like Danebury and Winklebury, were to provide extensive facilities for the storage and display of food, rather than large-scale consumption events, which are so evident at the midden sites. Disused grain storage pits provided 
receptacles for the occasional deposition of whole and fragmented bodies, as well as objects and the detritus associated with feasts. Whilst deposits such as these are relatively commonly found in Early Iron Age hillforts and settlement enclosures in Wessex, Hill (1995) revealed that these were infrequent events, and the quantities of materials recovered from hillforts are generally very small, contrasting again with the midden sites. Yet the two types of sites are frequently interpreted in the same way - as communal gathering sites which were centres for the production and consumption of objects and food - even though there is actually very little evidence that Early Iron Age hillforts, even those that were intensively occupied like Danebury, had a major role in either the production or distribution of objects (cf. Cunliffe 1991, 553). The infrequent occurrence of objects and production debris at Early Iron hillforts such as Quarley Hill, Figsbury, Woolbury, Danebury Early Phase, and Bury Hill 1 is often highlighted in the literature (Cunliffe 2000, 166; Cunliffe 2006, 159; Sharples 2010, fig. 3.14), and likewise, large deposits of feasting residues are rare.

Comparison with the archaeological evidence from the midden sites, which are of an entirely different character, and which formed through a different suite of communal activities such as feasting, metalworking and object production, and the exchange, fragmentation and deposition of objects on a large scale - strongly suggests that we should avoid models that homogenise our interpretations of the roles that different monument-types had in the mid-first millennium BC. Both the midden sites and the Early Iron Age hillforts were gathering sites, and both monument-types may have overlapped slightly chronologically, but both provided different opportunities and mechanisms for communities to create their relationships in this period.

\section{The animal bone assemblage}

The new chronological framework for East Chisenbury has implications for the context of the faunal assemblage. LBA/EIA midden sites typically comprise a higher proportion of pig specimens than is common in later prehistoric Britain. In assessing assemblage composition in terms of the number of identified specimens (NISP) of the main three domesticates (caprines, cattle and pigs), Whitchurch (21\%, Madgwick 2011b), Potterne (29\%, Locker 2000), Runnymede (20\%, Serjeantson 1996), Whitecross Farm, Wallingford (33\%, Powell and Clarke 2006) and Llanmaes (70\%, Madgwick and Mulville 2015a) all have unusually high numbers of pig remains. However, this pattern is not adhered to at Eldon's Seat (5\%, author's [RM] unpublished data). East Chisenbury comprises $13 \%$ pig specimens (Serjeantson et al. 2010) and is therefore not typical of a transition phase midden assemblage.

A reliance on caprines (58\%) and cattle (29\%) is more common in Iron Age Britain and caprine husbandry is particularly characteristic of Iron Age Wessex (Hambleton 1999, 43-46). This may be linked to the maintenance of large-scale arable economies (Cunliffe 2005) or to the region's topography and geology (Hambleton 1999, 46). The reliance on caprines becomes more prominent throughout the Iron Age, although NISP percentages between 50 and 60 are common in Early Iron Age Wessex (Hambleton 1999, 58). Therefore, East Chisenbury is, superficially at least, more characteristic of an Early Iron Age Wessex faunal assemblage in terms of taxonomic composition. However, site type must be considered as well as chronology. The East Chisenbury assemblage is typical of non-midden sites of the Late Bronze Age and Early Iron Age in southern Britain (see Madgwick et al. 2012b). Rockley Down, Dean Bottom (Maltby 1992), Roughground Farm (Jones 1993), La Sagesse (Bourdillon 1990), Barrow Hills, Radley (Levitan and Serjeantson 1999), and Caldicot 
(McCormick et al. 1997) all comprise between 4-14\% pig specimens. With the exception of La Sagesse (Hampshire) and Barrow Hills, Radley (Oxfordshire), all these assemblages are also dominated by caprines. No assemblages known to the authors from Late Bronze Age or Early Iron Age non-midden sites in southern Britain have greater than $20 \%$ pig specimens. Therefore, East Chisenbury could be considered more characteristic of a non-midden site in terms of its faunal assemblage, rather than being typically Early Iron Age.

A distinctive feature of the East Chisenbury assemblage is the prevalence of young caprines, with more than a third probably culled by the age of four months. This may indicate an economic model partially relying on sheep milking (Serjeantson et al. 2010, 63-4). This is very unusual in Iron Age Britain (Hambleton 1999, 70), although the LBA midden of Runnymede (Serjeantson 2007) and the LBA-EIA settlement of Old Down Farm (Maltby 1981) show comparable patterns. Therefore mortality profiles at East Chisenbury remain exceptional in light of the new chronology.

Overall, faunal economies of the Late Bronze Age do not differ radically from those of the Early Iron Age. Midden assemblages of these periods are exceptional in the greater reliance on pigs and although chronological resolution is limited, this does not appear to be phasespecific. As Hambleton (1999) highlights, there is considerable regional and chronological diversity in husbandry regimes in later prehistory and assemblages cannot easily be defined as characteristic of a certain period or region.

\section{Impact on Iron Age periodization}

Due to observed social transformations taking place around $800 \mathrm{cal} \mathrm{BC}$, such as a dramatic reduction in the quantity of metal in circulation, and an increase in midden deposition, the Late Bronze Age-Early Iron Age transition period is currently thought to have occurred over a relatively short period of time, with some specialists arguing for a transition as short as a century (c. 850-750 BC, Needham 2007, 40; c. 750-650 BC, Barclay et al. 2006, fig. 7.2), although there has been general agreement that it ended by $c .600 \mathrm{BC}$. The late continuation of East Chisenbury suggests that this transitional period was a much longer phenomenon, in Wessex at least, with the social processes traditionally associated with the transition period extending into the mid-fifth century BC. This has implications for the Early Iron Age period, and it may now be necessary to adjust Iron Age periodization in Wessex, pushing the start of this period forward to around the mid-fifth century BC. This works well with the published interpretations of scratched cordoned bowls (Buck and Litton 1995, table 40; Cunliffe 1995, 18; Cunliffe 2000, 163). The results also demonstrate that PDR decorated wares have a longer chronology, and there is a $99 \%$ probability for the assemblage from East Chisenbury that they extend into the fifth century cal BC.

That the Late Bronze Age-Early Iron Age transition lasts for a longer period than previously envisaged in Wessex is perhaps unsurprising. During the Llyn Fawr period, the focus for metalwork deposition moves from South-East England to Wessex, the Severn Valley and South Wales (O'Connor 2007). While it must be stressed that the numbers of bronze objects in circulation were relatively small by comparison to the preceding Ewart Park period, with only twenty-seven Llyn Fawr hoards reported in Britain (O'Connor 2007), communities in Wessex and south Wales continued to engage with bronze and they renewed exchange relationships with Brittany and Normandy (O'Connor 2007). This marks the region out as very different to neighbouring ones. The re-analysis of the large Llyn Fawr metalwork assemblage from Llanmaes recently by Gwilt et al. (2016) is relevant here, as LBA/EIA 
midden deposition at this site is now thought to span the mid-seventh to the mid-fifth centuries cal. BC (see above). This places the main phase of midden deposition at Llanmaes as broadly aligned with the main phase of the midden at East Chisenbury and Worth Mattravers (both in Wessex), and there may well be other midden sites in southern Britain that span this later period too.

\section{Conclusions}

This dating project has transformed the interpretation of the chronology of East Chisenbury, and it has pushed the occupation of this site, and its associated PDR decorated wares, to the later fifth century cal BC. We favour an interpretation that the midden is abandoned in the later fifth century cal $\mathrm{BC}$, and that it did not continue any later, due to the absence of scratch cordoned bowls from the site. This has implications for our understanding of the settlement and monument sequence in Wessex and on current understandings of Iron Age periodization models.

It is necessary to determine whether all of these sites belong to the same period, or whether some are earlier or later. One of the most interesting aspects of the pottery assemblages from Potterne and All Cannings Cross is the variation in decorative motifs, with some from All Cannings Cross not being visible in the Potterne assemblage, and vice versa. This might have a chronological significance. The presence of scratch cordoned bowls and La Tène 1 and 2 brooches at All Cannings Cross suggests that this site was occupied into the later part of the Early Iron Age. The presence of Ewart Park metalwork in the lower levels of the main midden sequence at Potterne suggests that large-scale depositional activities began here in the tenth and ninth centuries cal BC, contemporary with the earlier phase of primary ploughsoil midden deposition at East Chisenbury, but nearly two-hundred years before deposition at East Chisenbury intensified. Llyn Fawr metalwork occurs in the uppermost layers of the midden at Potterne, while it only occurs in the lowest layer in Trench A at East Chisenbury. It therefore seems highly possible that the midden sites in the Vale of Pewsey possess different histories, with some flourishing or diminishing at different times to others, and with some potentially overlapping for only limited periods of time. This variability is an extremely important factor which needs to be explored further.

This study demonstrates that it is possible to provide useful chronological resolution for the understanding of the Late Bronze Age-Iron Age transition in Britain despite the formidable plateau in the radiocarbon calibration curve. The results reveal that some adjustment is now required to the accepted periodisation model for the Late Bronze Age/Early Iron Age transition and the Early Iron Age, even if the chronology proposed here is specific only to northern Wessex. To verify the impact of these results across different regions in southern England, extensive radiocarbon dating programmes are required, which must be accompanied by strongly informative prior archaeological information on the relative sequence of samples (be it derived, as here, from stratigraphy or from seriation of artefact-types). Only when these two strands of evidence are combined using Bayesian statistical modelling can the challenges of the radiocarbon plateau be overcome. Midden sites that have clear stratigraphic sequences are one possible target (e.g. All Cannings Cross), as are early hillforts built on the site of previous occupation (e.g. Winklebury). Such research will undoubtedly transform current understandings of the chronology of this period in Britain. 


\section{Acknowledgements}

This project commenced during AHRC-funded $\mathrm{PhD}$ research by $\mathrm{KW}$ and $\mathrm{RM}$. The radiocarbon dates were funded by the NERC's programme (grant numbers NF/2008/2/8 and NF/2010/1/8). We thank the staff of the Oxford Radiocarbon Accelerator Unit (ORAU) for their careful work on the dating of the samples. We are grateful to David Field (English Heritage) and Lisa Brown (Wiltshire Heritage Museum) for facilitating sampling. Thanks go to John Barrett for providing comments on the results of the initial Bayesian model, to Lilian Ladle for providing details of previously unpublished radiocarbon measurements from Worth Matravers, and to Adam Gwilt for much feedback on the sequence from Llanmaes.

\section{References}

Allen, M, 2000. Taphonomy and species of the samples, in A. J. Lawson (ed.) Potterne 19825: Animal Husbandry in Later Prehistoric Wiltshire, 40-2, Salisbury: Trust for Wessex Archaeology (Report No. 17)

Allen, T., Cramp, K., Lamdin-Whymark, H. and Webley, L. 2010. Castle Hill and its Landscape; Archaeological Investigations at the Wittenhams, Oxfordshire, Oxford: Oxford Archaeology Monograph 9

Ambers, J. and Bowman, S. 1994. British Museum natural radiocarbon measurements XXIII, Radiocarbon 36:1, 95-111

Ambers, J. and Bowman, S. 1999. Radiocarbon measurements from the British Museum: datelist XXV, Archaeometry 41/1, 185-195

Ambers, J. and Leese, M. 1996. The radiocarbon results and their interpretation, in S. Needham and T. Spence (eds), Refuse and Disposal at Area 16 East, Runnymede. Runnymede Bridge Research Excavations, Volume 2, 78-82, London: British Museum Press

Armit, I., Neale, N., Shapland, F., Bosworth, H., Hamilton, W. D., and McKenzie, J., 2013. The ins and outs of death in the Iron Age: complex funerary treatments at Broxmouth Hillfort, East Lothian, Oxford Journal of Archaeology 32, 73-100

Barber, M. 2010. Metalwork, in D. McOmish, D. Field, and G. Brown (eds), The Late Bronze Age - Early Iron Age site at East Chisenbury, Wiltshire, The Wiltshire Archaeological and Natural History Magazine, 103, 78-81

Barclay, A., Cromarty, A. M., Lambrick, G., and Robinson, M. 2006. Synthesis: the wider regional and national context, in A. M. Cromarty, A. Barclay, G. Lambrick, and M. Robinson (eds), Archaeology of the Wallingford Bypass, 1986-92: Late Bronze Age Ritual and Habitation on a Thames Eyot at Whitecross Farm, Wallingford, 225-36, Oxford: Oxford Archaeology (Monograph no. 22) 
Accepted for publication in Archaeological Journal published by Taylor and Francis

Barrett, J. C. 1980. The pottery of the later Bronze Age in lowland England, Proceedings of the Prehistoric Society, 46, 297-319

Barrett, J. C. and McOmish, D. 2008. Early Iron Age transformations: middens around the Vale of Pewsey and the problems of process, unpublished paper presented at Unquiet residues: the 'midden' seminar, School of History and Archaeology: Cardiff University

Bayliss, A. 2009. Rolling out revolution: using radiocarbon dating in archaeology,

Radiocarbon 51, 123-47

Bayliss, A., Barclay, A., Cromarty, A. M., and Lambrick, G. 2006. Appendix 1: Radiocarbon dating, in A. M. Cromarty, A. Barclay, G. Lambrick, and M. Robinson (eds), Archaeology of the Wallingford Bypass, 1986-92: Late Bronze Age Ritual and Habitation on a Thames Eyot at Whitecross Farm, Wallingford, 237-39, Oxford: Oxford Archaeology (Monograph no. 22)

Bayliss, A., Bronk Ramsey, C., van Der Plicht, J., and Whittle, A., 2007. Bradshaw and Bayes: towards a timetable for the Neolithic, Cambridge Archaeological Journal, 17(1), 1-28

Bayliss, A., Evans, C., McCormac, F. G., and Bronk Ramsey, C. 2003. Absolute chronology, in C. Evans (ed.), Power and Island Communities: Excavations at the Wardy Hill ringwork, Coveney, Isle of Ely, East Anglia Archaeology, 103, 238-49

Bayliss, A., Hedges, R., Otlet, R., Switsur, R., and Walker, J. 2012. Radiocarbon Dates: from Samples funded by English Heritage between 1981 and 1988, Swindon: English Heritage

Bayliss, A., Jackson, R., and Bronk Ramsey, C. 2015. Radiocarbon dating, in R. Jackson (ed.), Huntsman's Quarry, Kemerton: A Late Bronze Age Settlement and Landscape in Worcestershire, 10-16, Oxford: Oxbow Books

Bayliss, A, van der Plicht, J, Bronk Ramsey, C, McCormac, G, Healy, F, and Whittle, A, 2011 Towards generational time-scales: the quantitative interpretation of archaeological chronologies, in Gathering time: dating the early Neolithic enclosures of southern Britain and Ireland (A Whittle, F Healy, and A Bayliss), 17-59, Oxford: Oxbow

Bayliss, A., Thomas, N., Bronk Ramsey, C., and McCormac, F. G. 2005. Interpreting chronology, in N. Thomas (ed.), Conderton Camp, Hereford and Worcester: A Small Middle Iron Age hillfort on Bredon Hill, 237-45, London: Council of British Archaeology (Research Report 143)

Bourdillon, J. 1990. The Animal Bones from La Sagesse (The Presbytery) 1988, Romsey, Hampshire, Unpublished Ancient Monuments Laboratory Report 106/90

Brock, F., Higham, T., Ditchfield, P., and Bronk Ramsey, C. 2010. Current pretreatment methods for AMS radiocarbon dating at the Oxford Radiocarbon Accelerator Unit (ORAU), Radiocarbon, 52, 103-12

Bronk Ramsey, C. 1995. Radiocarbon calibration and analysis of stratigraphy: the OxCal program, Radiocarbon, 36, 425-30 
Accepted for publication in Archaeological Journal published by Taylor and Francis

Bronk Ramsey, C., Higham, T., and Leach, P. 2004. Towards high-precision AMS: progress and limitations, Radiocarbon, 46, 17-24

Bronk Ramsey, C, 2009. Bayesian analysis of radiocarbon dates, Radiocarbon, 51, 337-60

Brown, L. 2000. The regional ceramic sequence, in B. Cunliffe (ed.), The Danebury Environs Programme: the Prehistory of a Wessex Landscape, Volume 1: Introduction, Oxford: Oxford University Committee for Archaeology (monograph no. 48)

Buck, C. E. and Litton, C. D. 1995. Further consideration of the Danebury dataset, in B. Cunliffe, Danebury, an Iron Age hillfort in Hampshire. Volume 6: a Hillfort Community in Perspective, 130-36, York: Council of British Archaeology (Archaeological Research Report 102)

Buck, C. E., Cavanagh, W. G., and Litton, C. D. 1996. Bayesian Approach to Interpreting Archaeological Data, Chichester: Wiley

Chochorowski, J., Krąpiec, M., Skoryj, S., and Skrypkin, V. 2014. Wiggle-match dating of tree-ring sequences from the early Iron Age defensive settlement Motroninskoe Gorodishche in Mielniki (central Ukraine), Radiocarbon, 56, 645-54

Cook, G. T., Dixon, T. N., Russell, N., Naysmith, P., Xu, S., and Andrian, B. 2010. Highprecision radiocarbon dating of the construction phase of Oakbank Crannog, Loch Tay, Perthshire, Radiocarbon, 52, 346-55

Cromarty, A. M., Barclay, A., Lambrick, G., and Robinson, M. (eds), 2006. Archaeology of the Wallingford Bypass, 1986-92: Late Bronze Age Ritual and Habitation on a Thames Eyot at Whitecross Farm, Wallingford, Oxford: Oxford Archaeology (Monograph no. 22)

Cunliffe, B. 1984. Danebury: An Iron Age Hillfort in Hampshire, London: Council for British Archaeology (Research Report 52)

Cunliffe, B. 1991. Iron Age Communities in Britain: an Account of England, Scotland and Wales from the Seventh Century BC until the Roman Conquest, Third Edition, London: Routledge

Cunliffe, B. 1995. Danebury, an Iron Age Hillfort in Hampshire. Volume 6: a Hillfort Community in Perspective, York: Council of British Archaeology (Archaeological Research Report 102)

Cunliffe, B. 2000. The Danebury Environs Programme, the Prehistory of a Wessex Landscape. Volume 1: Introduction, Oxford: Oxford University Committee for Archaeology (Monograph 48)

Cunliffe, B. 2005. Iron Age Communities in Britain: an Account of England, Scotland and Wales from the Seventh Century BC until the Roman Conquest, Fourth Edition, Abingdon: Routledge 
Accepted for publication in Archaeological Journal published by Taylor and Francis

Cunliffe, B. 2006. Understanding hillforts: have we progressed? In A. Payne, M. Corney, and B. Cunliffe. The Wessex Hillforts Project: Extensive Survey of Hillfort Interiors in Central Southern England, 151-62, London: English Heritage

Cunliffe, B. and Phillipson, D. W. 1968. Excavations at Eldon's Seat, Encombe, Dorset. Proceedings of the Prehistoric Society, 34, 191-237

Cunnington, M. E. 1923. The Early Iron Age inhabited site at All Cannings Cross Farm, Wiltshire, Devizes: G. Simpson

Dee, M. and Bronk Ramsey, C. 2000. Refinement of graphite target production at ORAU, Nuclear Instruments and Methods Physics Research B, 172, 449-53

Ellis, C. J. and Rawlings, M. 2001. Excavations at Balksbury Camp, Andover 1995-97. Proceedings of the Hampshire Field Club Archaeological Society, 56, 21-94.

Garrow, D., Gosden, C., Hill, J. D., and Bronk Ramsey, C. 2009. Dating Celtic Art: a major radiocarbon dating programme of Iron Age and early Roman metalwork in Britain, Archaeological Journal, 166, 79-123

Gingell, C. J., Lawson, A. J., and Mortimer, C. 2000. Copper alloy objects, in A. J. Lawson (ed.), Potterne 1982-5: Animal Husbandry in Later Prehistoric Wiltshire, 186-98, Salisbury: English Heritage (Wessex Archaeology Report No. 17)

Graham, A. H., Hinton, D. A., and Peacock, D. P. S. 2002. The excavation of a RomanoBritish settlement in Quarry Field, south of Compact Farm, Worth Matravers, in Dorset, in D. Hinton (ed.), Purbeck Papers, 1-83, Oxford: Oxbow Books

Guttmann, E. B. A. 2005. Midden cultivation in prehistoric Britain: arable crops in gardens, World Archaeology 37(2), 224-39

Gwilt, A., Lodwick, M. and Deacon, J. 2006. Excavation at Llanmaes, Vale of Glamorgan, 2006, Archaeology in Wales, 46, 15-24

Gwilt, A. and Lodwick, M. 2008. Recent Feildwork at Llanmaes, Vale of Glamorgan, Archaeology in Wales, 48, 67-69

Gwilt, A., Lodwick, M., Deacon, J., Wells, N., Madgwick, R., and Young, T. 2016. Ephemeral abundance at Llanmaes: exploring the residues and resonances of an Earliest Iron Age midden and its associated archaeological context in the Vale of Glamorgan, in J. T. Koch and B. Cunliffe (eds), Celtic from the West 3. Atlantic Europe in the Metal Ages: Questions of Shared Language, 294-329, Oxford: Oxbow Books (Celtic Studies Publications)

Harding, D. W. 1987. Excavations in Oxfordshire 1964-66, Edinburgh: University of Edinburgh Department of Archaeology (Occasional Paper 15)

Hamilton, W. D. 2011. The use of radiocarbon and Bayesian modelling to (re)write late Iron Age settlement histories in east-central Britain, University of Leicester: unpublished $\mathrm{PhD}$ thesis 
Hamilton, D., McKenzie, J., Armit, I., and Büster, L. 2013. Chronology: radiocarbon dating and Bayesian modelling, in I Armit and J. McKenzie (eds), An Inherited Place: Broxmouth Hillfort and the South-East Scottish Iron Age, 191-224, Edinburgh: Society of Antiquaries Scotland

Hamilton, W. D., Haselgrove, C., and Gosden, C. 2015. The impact of Bayesian chronologies on the British Iron Age, World Archaeology, 47(4), 642-60.

Haselgrove, C. and Pope, R. 2007. Characterising the Earlier Iron Age, in C. Haselgrove and P. Pope (eds), The Earlier Iron Age in Britain and the Near Continent, 1-23, Oxford: Oxbow Books.

Hambleton, E. 1999. Animal Husbandry Regimes in Iron Age Britain: a Comparative Study of Faunal Assemblages from British Iron Age Sites, Oxford: British Archaeological Reports (British Series 282)

Hey, G., Bayliss, A., and Boyle, A. 1998. Iron Age inhumation burials at Yarnton, Oxfordshire, Antiquity, 73, 551-62

Higham, T. F. G., Bronk Ramsey, C., Brock, F., Baker, D., and Ditchfield, P. 2007. Radiocarbon Dates from the Oxford AMS System: Archaeometry Datelist 32, Archaeometry, 49(S1), 1-60

Hill, J. D. 1995. Ritual and Rubbish in the Iron Age of Wessex: a Study on the Formation of a Specific Archaeological Record, Oxford: British Archaeological Reports (British Series 242)

Hingley, R. 1979-80. Excavations by R. A. Rutland on an Iron Age site at Wittenham Clumps, Berkshire Archaeological Journal, 70, 21-55

Jacobsson, P., Hamilton, W. D., Cook, G., Crone, A., Dunbar, E., Kinch, H., Naysmith, P., Tripney, B., and $\mathrm{Xu}, \mathrm{S} .2017$. Refining the Hallstatt plateau: Short-term ${ }^{14} \mathrm{C}$ variability and small scale offsets in 50 consecutive tree-rings from south west Scotland dendro-dated to 410-460 BC, Radiocarbon, 60, 219-37

Jay, M., Haselgrove, C., Hamilton, D., Hill, J. D., and Dent, J. 2012. Chariots and context: radiocarbon dates from Wetwant Slack and the chronology of the East Yorkshire Iron Age burial tradition and brooch sequence, Oxford Journal of Archaeology, 31, 161-89

Jones, G. G. 1993. Animal bones, in T. Allen, T. Darvill, L. Green and M. Jones (eds), Excavations at Roughground Farm, Lechlade, Gloucestershire: a Prehistoric and Roman Landscape, 34-35, Thames Valley Landscapes 1, Oxford: Oxford Archaeological Unit

Jordan, D., Haddon-Reece, D., and Bayliss, A. 1994. Radiocarbon Dates from Samples funded by English Heritage and dated before 1981, London: English Heritage

Kromer, B., Manning, S. W., Friedrich, M., Talamo, S., and Trano, N. 2010. ${ }^{14} \mathrm{C}$ calibration in the 2nd and 1st millennia BC: Eastern Mediterranean Radiocarbon Comparison Project (EMRCP), Radiocarbon, 52, 875-86 
Accepted for publication in Archaeological Journal published by Taylor and Francis

Kuzmin, Y. V., Slusarenko, I. Y., Hajas, I., Bonani, G., and Christen, J. A. 2004. The comparison of ${ }^{14} \mathrm{C}$ wiggle-matching results for the 'floating' tree-ring chronology of the Ulandryk-4 burial ground (Altai mountains, Siberia), Radiocarbon, 46, 943-48

Ladle, L. Forthcoming. Life, Death and Feasting: 5600 Years of Occupation Revealed at Football Field, Worth Matravers, Dorset 2006-2011

Lawson, A. J. 2000. Potterne 1982-5: Animal Husbandry in Later Prehistoric Wiltshire, Salisbury: Trust for Wessex Archaeology (Report No. 17)

Lawson, A., Allen, M. J., and Bayliss, A. 2000. Radiocarbon dating, in A. J. Lawson (ed.), Potterne 1982-5: Animal Husbandry in Later Prehistoric Wiltshire, 39-42, Salisbury: Trust for Wessex Archaeology (Report No. 17)

Lawson, A., Powell, A., Thomas, R. 2000. Discussion, in A. J. Lawson (ed.), Potterne 19825: Animal Husbandry in Later Prehistoric Wiltshire, 250-72, Salisbury: Trust for Wessex Archaeology (Report No. 17)

Leivers, M. 2015. Prehistoric pottery, in J. I. McKinley, M. Leivers, J. Schuster, P. Marshall, A. J. Barclay, and N. Stoodley, Cliff's End Farm, Isle of Thanet, Kent: a Mortuary and Ritual Site of the Bronze Age, Iron Age, and Anglo-Saxon Period with Evidence for Long-distance Maritime Mobility, 145-59, Salisbury, Wessex Archaeology (Monograph No. 31)

Levitan, B. and Serjeantson, D. 1999. Animal bone, in A. Barclay and C. Halpin (eds), Excavations at Barrow Hills, Radley, Oxfordshire. Volume 1. The Neolithic and Bronze Age monument complex, 236-41, Thames Valley Landscapes Volume 11, Oxford: Oxford Archaeology

Locker, A. 2000. Animal bone, in A. J. Lawson (ed.), Potterne 1982-5: Animal Husbandry in Later Prehistoric Wiltshire, 101-17. Salisbury: Trust for Wessex Archaeology (Report No. 17)

Longley, D. 1980. Runnymede Bridge 1976: Excavations on the Site of a Late Bronze Age Settlement, Guildford: Surrey Archaeological Society (Research Volume 6)

Macphail, R. I. 2000. Soils and microstratigraphy: a soil micromorphological and microchemical approach, in A. J. Lawson (ed.), Potterne 1982-5: Animal Husbandry in Later Prehistoric Wiltshire, 47-70, Salisbury: Trust for Wessex Archaeology (Report No. 17)

Macphail, R. I. 2010. Soil micromorphology, in D. McOmish, D. Field and G. Brown (eds), The Late Bronze Age - Early Iron Age site at East Chisenbury, Wiltshire, The Wiltshire Archaeological and Natural History Magazine, 103, 53-62

Madgwick, R. 2011a. Investigating the Potential of Holistic Taphonomic Analysis in Zooarchaeological Research, Cardiff University: unpublished Ph D thesis 
Accepted for publication in Archaeological Journal published by Taylor and Francis

Madgwick, R. 2011b. The faunal assemblage, in K. Waddington and N.M. Sharples, The Whitchurch Excavations 2006-2009: an Interim Report, 53-55, Cardiff: Cardiff Studies in Archaeology (Specialist Report no. 29)

Madgwick, R, 2016. New light on feasting and deposition: exploring accumulation history through taphonomic analysis at later prehistoric middens in Britain, Archaeological and Anthropological Sciences, 8, 329-41.

Madgwick, R, and Mulville, J, 2015a. Feasting on forelimbs: conspicuous consumption and identity in later prehistoric Britain, Antiquity 89, 629-44

Madgwick, R, and Mulville, J, 2015b. Reconstructing depositional histories through bone taphonomy: extending the potential of faunal data, Journal of Archaeological Science, 53, 255-63.

Madgwick, R., Mulville, J., and Evans, J. 2012a. Investigating diagenesis and the suitability of porcine enamel for strontium (Sr-87/Sr-86) isotope analysis, Journal of Analytical Atomic Spectrometry, 27, 733-42

Madgwick, R., Mulville, J., and Stevens, R. E. 2012b. Diversity in foddering strategy and herd management in late Bronze Age Britain: an isotopic investigation of pigs and other fauna from two midden sites, Environmental Archaeology, 17, 126-40

Maltby, J. M. 1981. Animal bone, in S. M. Davies (ed.), Excavations at Old Down Farm, Andover, Proceedings of the Hampshire Field Club and Archaeological Society, 37, 81-163

Maltby, J. M. 1992. The animal bone, in C. Gingell (ed.), The Marlborough Downs: a Late Bronze Age Landscape and its Origins, 137-42, Salisbury: Wiltshire Archaeological and Natural History Society (Monograph 1)

Marshall, P., Barclay, A. J., Bayliss, A., Bronk Ramsey, C., Cook, G., Grootes, P. M., Meadows, J., and van der Plicht, J. 2015. Chronology and the radiocarbon dating programme, in J. I. McKinley, M. Leivers, J. Schuster, P. Marshall, A. J. Barclay, and N. Stoodley, Cliff's End Farm, Isle of Thanet, Kent: a Mortuary and Ritual Site of the Bronze Age, Iron Age, and Anglo-Saxon Period with Evidence for Long-distance Maritime Mobility, 65-92, Salisbury: Wessex Archaeology (Monograph 31)

McCormick, F., Hamilton-Dyer, S. and Murphy, E. 1997. The animal bones, in N. Nayling and A. Caseldine (eds), Excavations at Caldicot, Gwent: Bronze Age Palaeochannels in the Lower Nedern Valley, 218-41, London: Council for British Archaeology (Research Report No. 108)

McOmish, D. 1996. East Chisenbury: ritual and rubbish at the British Bronze Age-Iron Age transition, Antiquity, 70, 68-76

McOmish, D., Field, D., and Brown, G. 2002. The field archaeology of the Salisbury Plain Training Area, London: English Heritage 
Accepted for publication in Archaeological Journal published by Taylor and Francis

McOmish, D., Field, D. and Brown, G., 2010. The Bronze Age and Early Iron Age Midden Site at East Chisenbury, Wiltshire. The Wiltshire Archaeological and Natural History Magazine, 103, 35-101

Morris, E. 2000. Pottery, in A. J. Lawson (ed.), Potterne 1982-5: Animal Husbandry in Later Prehistoric Wiltshire, 136-77, Salisbury: Trust for Wessex Archaeology (Report No. 17)

Morris, E. 2013. The Middle to Late Bronze Age ceramic transition in the Lower Kennet Valley and beyond, in A. Brossler, F. Brown, E. Guttmann, E. Morris, and L. Webley, Prehistoric Settlement in the Lower Kennet Valley: Excavations at Green Park (Reading Business Park) Phase 3 and Moores Farm, Burghfield, Berkshire, 103-115, Oxford: Oxford Archaeology (Thames Valley Landscape Monographs, Volume 37)

Needham, S. P. 1990. The Petters Late Bronze Age Metalwork: an Analytical Study of Thames Valley Metalworking in its Settlement Context, London: British Museum Press

Needham, S. P. 1991. Excavation and Salvage at Runnymede Bridge, 1978: the Late Bronze Age Waterfront Site, London: British Museum Press

Needham, S. P. 1996. Chronology and periodization in the British Bronze Age, Acta Archaeologica 67, 121-40

Needham, S. P. (ed.) 2000. The Passage of the Thames: Holocene Environment and Settlement at Runnymede, London: British Museum Press

Needham, S. P. 2007. 800 BC. The Great Divide, in C. Haselgrove and P. Pope (eds) The Earlier Iron Age in Britain and the near Continent, 39-63, Oxford: Oxbow Books

Needham, S. P., Bronk Ramsay, C., Coombs, D., Cartwright, C., and Pettit, P. 1997. An independent chronology for British Bronze Age metalwork: the results of the Oxford radiocarbon accelerator programme, Archaeological Journal, 154, 55-107

Needham, S. P. and Spence, T. (eds) 1996. Refuse and Disposal at Area 16 East, Runnymede. Runnymede Bridge Research Excavations, Volume 2, London: British Museum Press

Needham, S. P., and Spence, T. 1997. Refuse and the formation of middens, Antiquity, 71, $77-90$

Needham, S. P., Woodward, A., and Ambers, J. Forthcoming. Eldon's Seat: Refining the Bronze Age Sequence

O'Connor, B. 2007. Llyn Fawr metalwork in Britain: a review, in C. Haselgrove and R. Pope (eds), The Earlier Iron Age in Britain and the Near Continent, 64-79, Oxford: Oxbow Books

Outram, Z., Batt, C. M., Rhodes, E .J., and Dockrill, S. J. 2010. The integration of chronological and archaeological information to date building construction: an example from Shetland, Scotland, UK, Journal Archaeological Science, 37, 2821-30 
Accepted for publication in Archaeological Journal published by Taylor and Francis

Powell, A. and Clark, K. M. 2006. Animal bone, in A. M. Cromarty, A. Barclay, G.

Lambrick, and M. Robinson, Late Bronze Age Ritual and Habitation on a Thames Eyot at Whitecross Farm, Wallingford. The Archaeology of the Wallingford Bypass 1986-92, 10510. Oxford: Oxford Archaeology (Thames Valley Landscapes Monograph Volume 22)

Quarta, G., Pezzo, M. I., Marconi, S., Tecchiati, U., D’Elia, M., and Calcagnile, L. 2010. Wiggle-match dating of wooden samples from Iron Age sites in Northern Italy, Radiocarbon, $52,915-23$

Raymond, F. 2010. Pottery, in D. McOmish, D. Field and G. Brown (eds), The Late Bronze Age - Early Iron Age site at East Chisenbury, Wiltshire, The Wiltshire Archaeological and Natural History Magazine, 103, 66-69

Reimer, P. J., Bard, E., Bayliss, A., Beck, J. W., Blackwell, P., Bronk Ramsey, C., Buck, C. E., Cheng, H., Edwards, R. L., Friedrich, M., Grootes, P. M., Guilderson, T. P., Haflidason, H. Hajdas, I., Hatté, C., Heaton, T. J., Hoffmann, D. L., Hogg, A. G., Hughen, K. A., Kaiser, K. F., Kromer, B., Manning, S. W., Niu, M., Reimer, R. W., Richards, D. A., Scott, E. M., Southon, J. R., Staff, R. A., Turney, C. S. M., and van der Plicht, J. 2013. IntCal13 and Marine13 radiocarbon age calibration curves 0-50,000 years cal BP, Radiocarbon, 55, 186987

Serjeantson, D. 1996. The animal bones, in S. Needham and T. Spence (eds), Runnymede Bridge Research Excavations. Volume 2, Refuse and Disposal at Area 16 East, Runnymede, 194-223, London: British Museum Press

Serjeantson, D. 2007. Intensification of animal husbandry in the Late Bronze Age? The contribution of sheep and pigs, in C. Haselgrove and R. Pope (eds.), The Earlier Iron Age in Britain and the Near Continent, 80-93, Oxford: Oxbow Books

Serjeantson, D., Bagust, J., and Jenkins, C. 2010. Animal bone, in D. McOmish, D. Field and G. Brown (eds), The Late Bronze Age - Early Iron Age site at East Chisenbury, Wiltshire, The Wiltshire Archaeological and Natural History Magazine, 103, 35-101.

Sharples, N. M. 2007. Building communities and creating identities in the first millennium $\mathrm{BC}$, in C. Haselgrove and R. Pope (eds.), The Earlier Iron Age in Britain and the Near Continent, 174-84, Oxford: Oxbow Books

Sharples, N. M. 2010. Social Relations in Later Prehistory: Wessex in the First Millennium $B C$, Oxford: Oxford University Press

Smith, K. 1977. The excavation of Winklebury Camp, Basingstoke, Hampshire, Proceedings of the Prehistoric Society, 43, 31-130

Steier, P. and Rom, W. 2000. The use of Bayesian statistics for ${ }^{14} \mathrm{C}$ dates of chronologically ordered samples: a critical analysis, Radiocarbon, 42, 183-98

Steier, P., Rom, W., and Puchegger, S. 2001. New methods and critical aspects in Bayesian mathematics for ${ }^{14} \mathrm{C}$ calibration, Radiocarbon, 43, 373-80 
Accepted for publication in Archaeological Journal published by Taylor and Francis

Stuiver, M. and Reimer, P. J. 1993. Extended ${ }^{14} \mathrm{C}$ data base and revised CALIB $3.0{ }^{14} \mathrm{C}$ age calibration program, Radiocarbon, 35, 215-30

Suzuki, K., Sakurai, H., Takahashi, Y., Sato, T., Gunji, S., Tokanai, F., Matsuzaki, H., and Tsuchiya, Y. 2010. Precise comparison of ${ }^{14} \mathrm{C}$ ages from Choukai Jindai cedar with IntCal04 raw data, Radiocarbon, 52, 1599-1609

Taylor, R. E. and Southon J. 2013. Reviewing the mid-first millennium BC ${ }^{14} \mathrm{C}$ "warp" using ${ }^{14} \mathrm{C} /$ bristlecone pine data, Nuclear Instruments and Methods in Physics Research B, 294, 4403

Thomas, R., Robinson, M., Barrett, J. and Wilson, B. 1986. The Late Bronze Age riverside settlement at Wallingford, Oxfordshire, Archaeological Journal, 143, 174-200

Tubb, P. 2011. The LBA/EIA Transition in the Vale of Pewsey, Wiltshire, Oxford:

Archaeopress (British Archaeological Reports, British Series 543)

Tullett, A. 2011. Social Transformations from the Middle Bronze Age to Middle Iron Age in Central Southern England, Leicester University: unpublished Ph D thesis

Waddington, K. E. 2009. Re-assembling the Bronze Age: Exploring the Southern British Midden Sites, Cardiff University: unpublished Ph D thesis

Waddington, K. E. Forthcoming. Creative Destruction: A Study of Deposits from the Late Bronze Age - Early Iron Age Midden at Potterne in Wiltshire

Waddington, K. E. and Sharples, N. 2011. The Whitchurch Excavations 2006-9: an Interim Report. Cardiff University: Cardiff Studies in Archaeology (Specialist Report no. 29)

Wainwright, G. J. and Davies S. M. 1995. Balksbury Camp, Hampshire. Excavations 1973 and 1981, London: English Heritage (Archaeological Report No. 4)

Ward, G. K. and Wilson, S. R. 1978. Procedures for comparing and combining radiocarbon age determinations: a critique, Archaeometry, 20, 19-31

Wessex Archaeology 2004a. Westbury Proposed Eastern By-Pass, Wiltshire: Stage 3 Additional Archaeological Evaluation, Wiltshire: The Trust for Wessex Archaeology Ltd (Unpublished client report 57070.02)

Wessex Archaeology 2004b. Proposed Westbury Eastern By-Pass, Wiltshire: Archaeological Augur Survey of the Deposit Site, Wiltshire: The Trust for Wessex Archaeology Ltd (unpublished client report 54100.03)

Wessex Archaeology 2017. East Chisenbury midden, Salisbury Plain, Wiltshire. Archaeological Evaluation Report. Wiltshire: The Trust for Wessex Archaeology Ltd (unpublished report 70241.01)

Whittle, A. and Bayliss, A. 2007. The times of their lives: from chronological precision to kinds of history and change, Cambridge Archaeological Journal, 17:1, 21-8 
Accepted for publication in Archaeological Journal published by Taylor and Francis

Woodward, A. 2009. The pottery, in L. Ladle and A. Woodward, Excavations at Bestwall Quarry, Wareham 1992-2005. Volume 1: the Prehistoric Landscape, 200-71, Dorset: Dorset Natural History and Archaeological Society (Dorset History and Monograph Series, Number 19).

Woodward, A. and Jackson, P. 2015. Prehistoric pottery, in R. Jackson (ed.), Huntsman's Quarry, Kemerton: a Late Bronze Age Settlement and Landscape in Worcestershire, 66-99, Oxford: Oxbow Books

Woodward, P. J. 1986. The excavation of an Iron Age and Romano-British settlement at Rope Lake Hole, Corfe Castle, Dorset, in J. Draper (ed.), Romano-British Industries in Purbeck, 125-80, Dorset: Dorset Natural History and Archaeology Society (Monograph Series No. 6) 